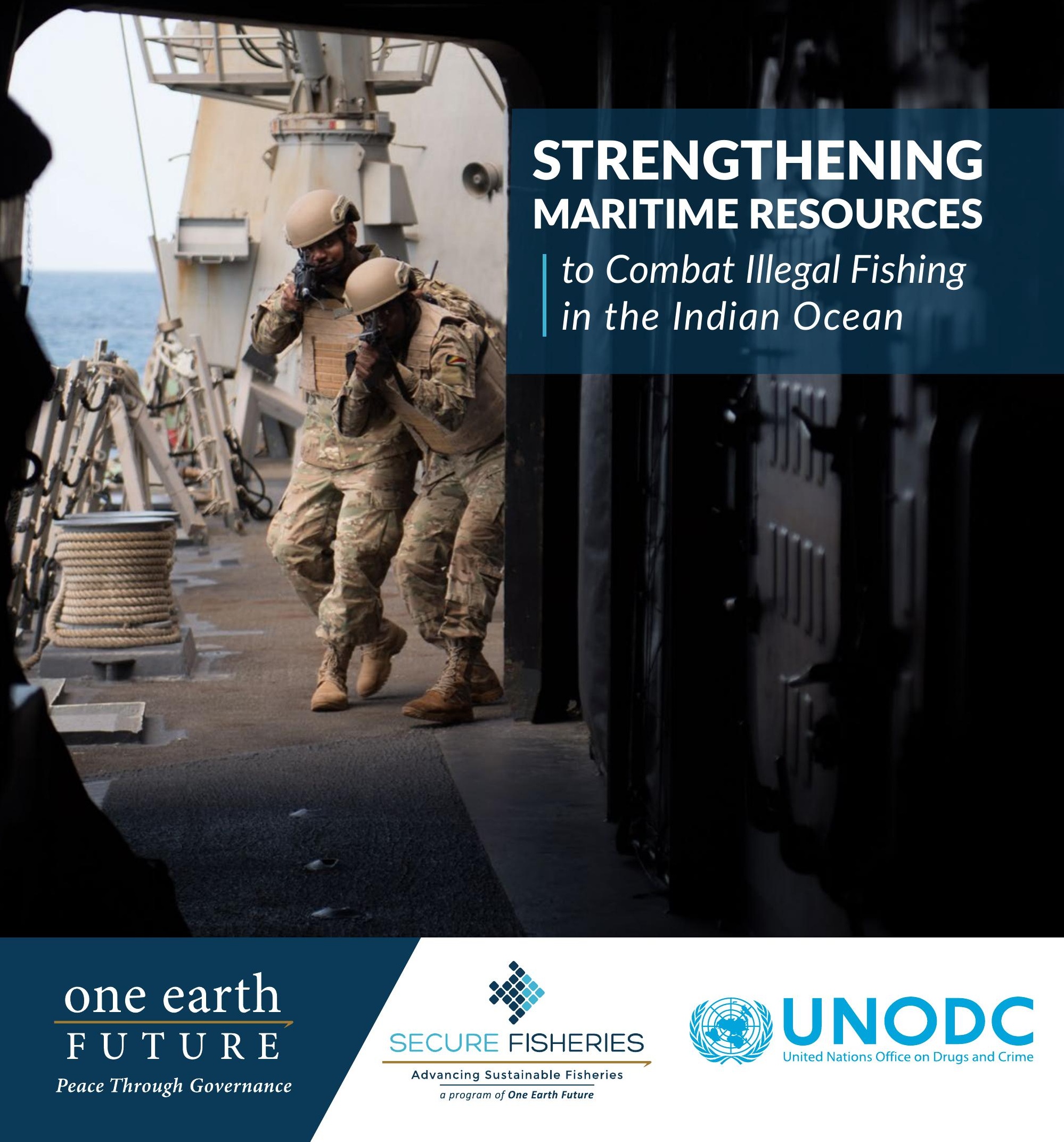




\section{STRENGTHENING MARITIME RESOURCES TO COMBAT ILLEGAL FISHING IN THE INDIAN OCEAN}

| Robert Mazurek

August 2019 


\section{TABLE OF CONTENTS}

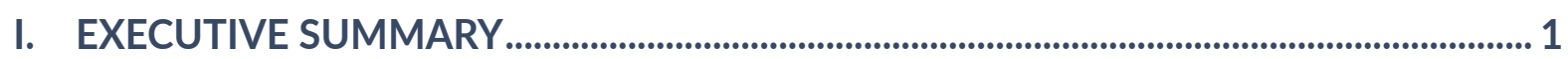

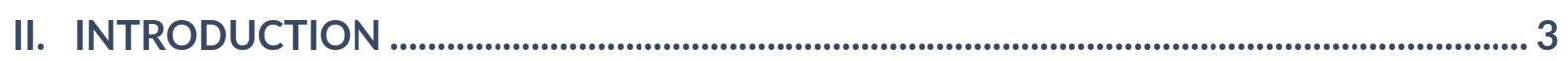

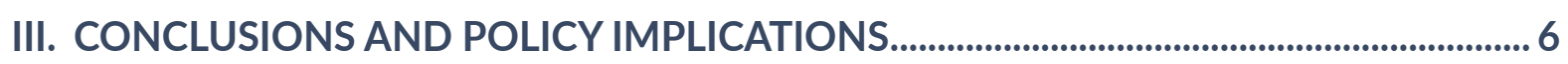

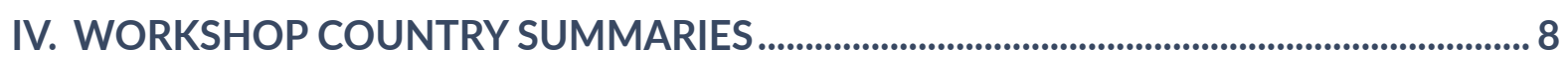

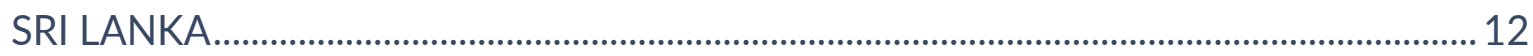

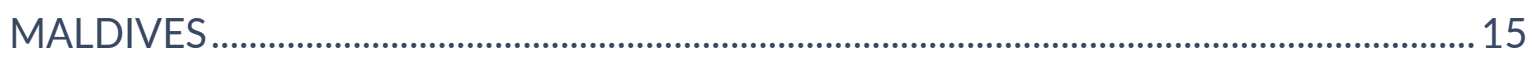

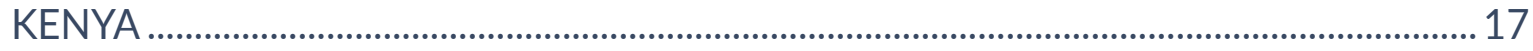

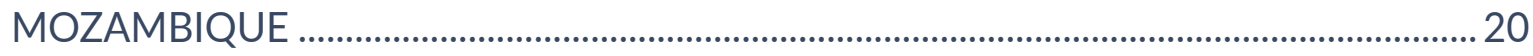

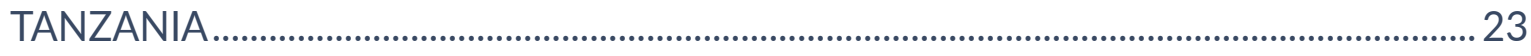

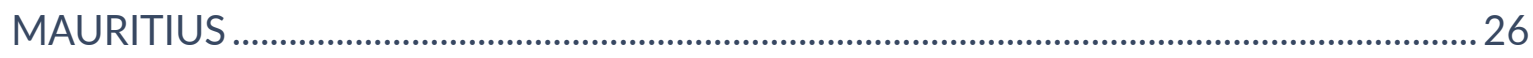

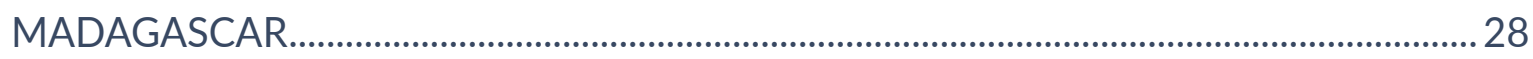

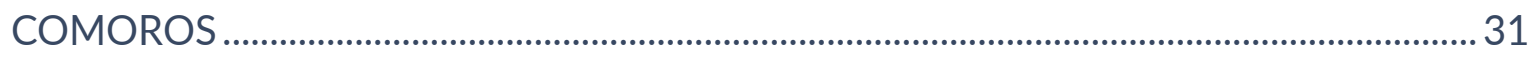

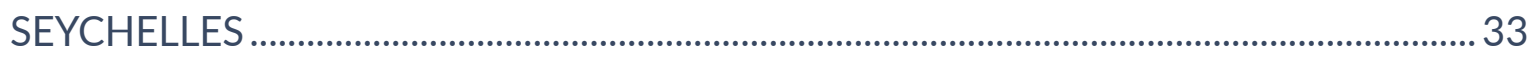

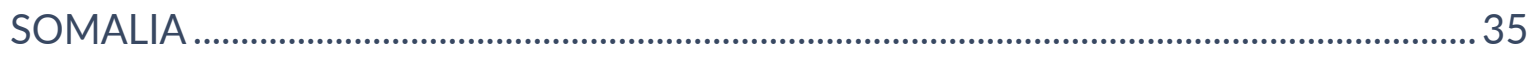

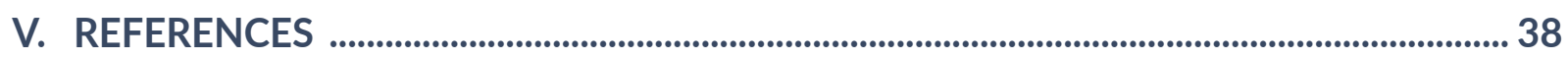

VI. APPENDIX: FISHERIES ACTIVITY SIGHTING REPORT ..................................................4 


\section{EXECUTIVE SUMMARY}

Indian Ocean coastal states have a shared interest in the management and conservation of the region's fisheries resources, which are critical to ensuring food and economic security and provide food to hundreds of millions of people. Illegal fishing, overfishing, and climate change have caused a reduction of major fish stocks within the region.

As Indian Ocean fish stocks have declined in recent years, there has been increased action to combat illegal fishing in order to ensure continued food and economic security in the region. However, there is growing concern that most Indian Ocean states still lack the basic resources and capabilities needed to monitor their maritime domains and regulate maritime activities to prevent illegal fishing and ensure food security.

This concern spurred a unique partnership between One Earth Future's (OEF) Secure Fisheries program, the United Nations Office on Drugs and Crime's (UNODC) Global Maritime Crime Programme, and US Naval Forces Africa (NAVAF) to conduct a series of workshops during 2018 in ten Western Indian Ocean states to advance interagency collaboration on illegal fishing and promote low-cost improvements for the collection of human intelligence on vessels suspected of illegal fishing.

Delegates from the Caught Red-Handed workshops concluded that:

- there is a problematic gap between agencies with capacity and agencies with mandates related to illegal fishing;

- state agencies that have the most maritime resources, including patrol vessels, aircraft, and satellite capabilities, need stronger mandates to fight fisheries-related crime;

- there must be a reprioritization of resources and improved coordination between fisheries and non-fisheries agencies to achieve better maritime domain awareness and fight illegal fishing; and

- $\quad$ states must create a governmental framework that will ensure state-based maritime agencies are in close collaboration and coordination, and that these agencies are aligned with regional and international efforts to fight illegal fishing.

Caught Red-Handed provided a venue for collaboration and information sharing, but there is still much to be done. For Indian Ocean states to address maritime crime and conflict, illegal fishing must be prioritized, and agencies must be empowered with the resources and mandates to fight it.

Three state-based actions are essential to ending illegal fishing in the Western Indian Ocean:

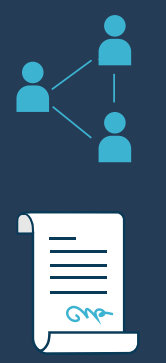

\section{ACTION 1: CREATION OF A COORDINATION TASK FORCE AGAINST ILLEGAL FISHING}

This would be the primary national mechanism for information sharing, coordination, and collaboration between maritime agencies in the fight against illegal fishing.

\section{ACTION 2: STRENGTHENING OF MANDATES AGAINST ILLEGAL FISHING FOR MARITIME AGENCIES}

All relevant maritime agencies should receive new or updated mandates that allow them to act on and prioritize illegal fishing. These proposed mandates would recognize that all maritime agencies have a role to play in fighting illegal fishing and would create a framework for effective interagency collaboration and coordination.

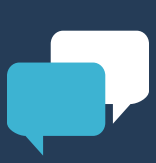

ACTION 3: DEVELOPMENT OF POLICIES FOR SHARING INFORMATION ON ILLEGAL FISHING WITH EXTERNAL PARTNERS

Maritime agencies are often hindered from sharing information because they lack a trusted network of peers and a way to securely exchange sensitive information, and have internal protocols that often prevent information exchange. 

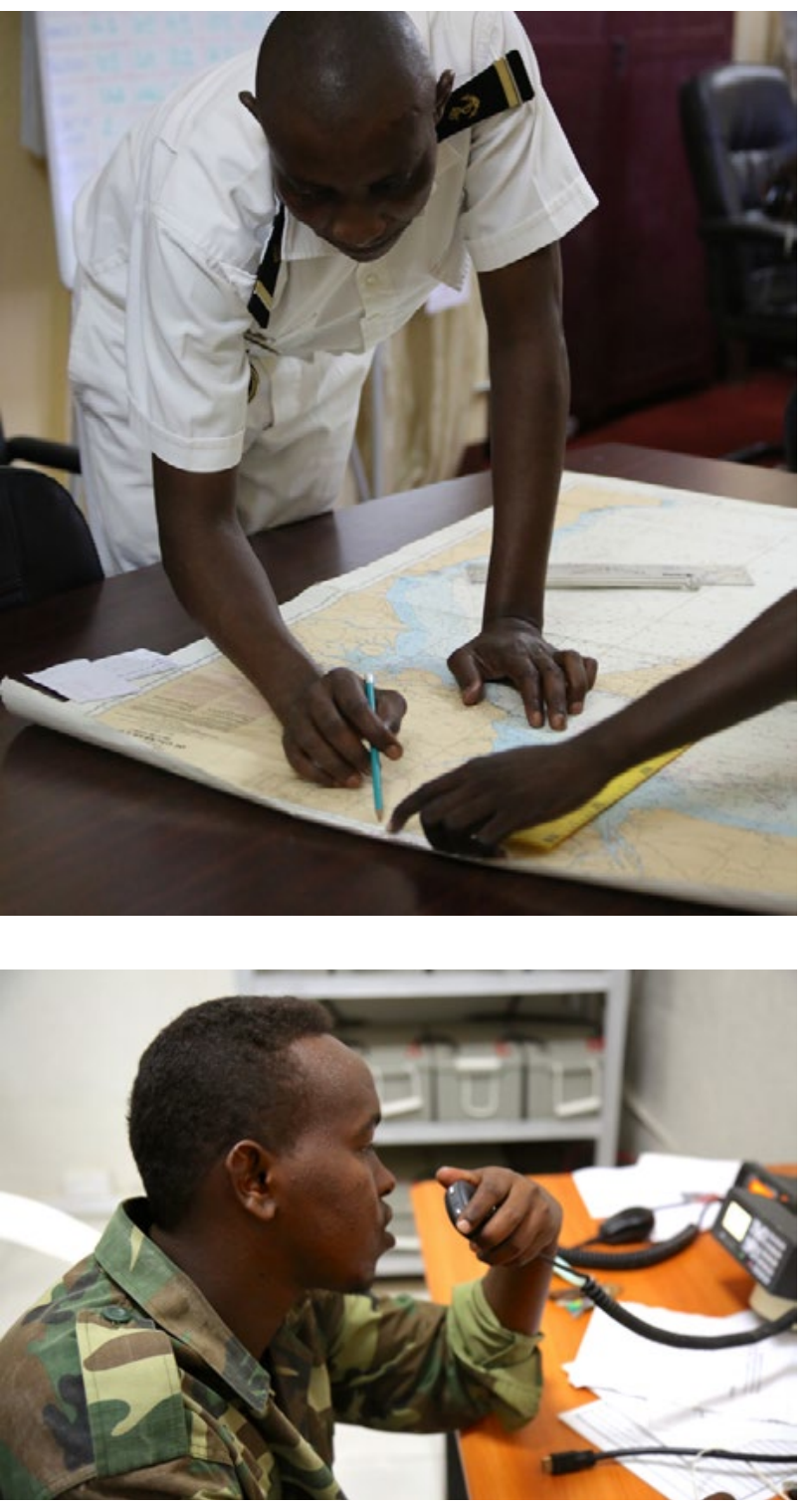

Top left: Officers study a map at a maritime information center. Photo: Jean-Pierre Larroque, One Earth Future.

Top right: A Mauritian boarding team crosses the bow of guidedmissile frigate USS Simpson (FFG 56) during a training exercise. Photo: David R. Krigbaum, US Navy.

Bottom left: A Somali officer radios information at a maritime operations center. Photo: Jean-Pierre Larroque, One Earth Future.

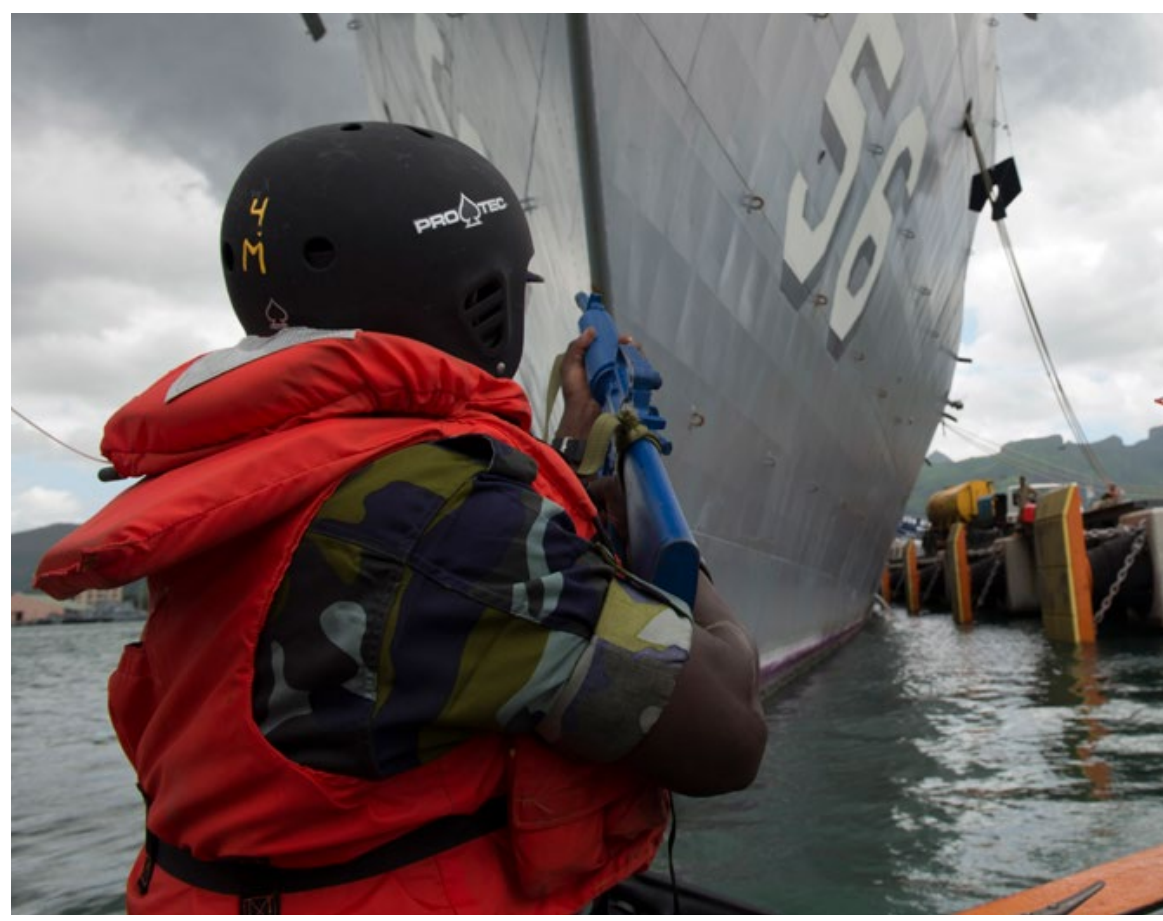

\section{LIST OF ACRONYMS}

$\begin{array}{ll}\text { AFRICOM } & \text { US Africa Command } \\ \text { AIS } & \text { Automatic identification system } \\ \text { EEZ } & \text { Exclusive economic zone } \\ \text { FAO } & \text { Food and Agriculture Organization } \\ \text { GMCP } & \text { Global Maritime Crime Programme } \\ \text { INTERPOL } & \text { International Criminal Police Organization } \\ \text { IOTC } & \text { Indian Ocean Tuna Commission } \\ \text { IUU } & \text { Illegal, unreported, and unregulated } \\ \text { MASE } & \text { Program to Promote Regional Maritime Security } \\ \text { MCS } & \text { Monitoring, control, and surveillance } \\ \text { MDA } & \text { Maritime domain awareness } \\ \text { NAVAF } & \text { US Naval Forces Africa } \\ \text { OEF } & \text { One Earth Future } \\ \text { PSMA } & \text { Port State Measure Agreement } \\ \text { RCOC } & \text { Regional Coordination Operations Center } \\ \text { RMIFC } & \text { Regional Maritime Information Fusion Center } \\ \text { UNODC } & \text { United Nations Office onf Drugs and Crime } \\ \text { VMS } & \text { Vessel monitoring system }\end{array}$




\section{INTRODUCTION}

The Indian Ocean's littoral states share a collective interest in managing and conserving the region's fisheries resources, which are critical to ensuring food and economic security. Indian Ocean fisheries provide food to hundreds of millions of people and also make important contributions to alleviating poverty, creating jobs, and improving livelihoods.

About 282,250 metric tons of tuna are consumed annually within Indian Ocean countries, equaling 56 percent of world tuna volume, with Indonesia representing the largest market. ${ }^{1}$ In Indonesia, Sri Lanka, Comoros, and the Maldives, tuna and other pelagic species account for more than half of the animal protein consumed. Maldivians are

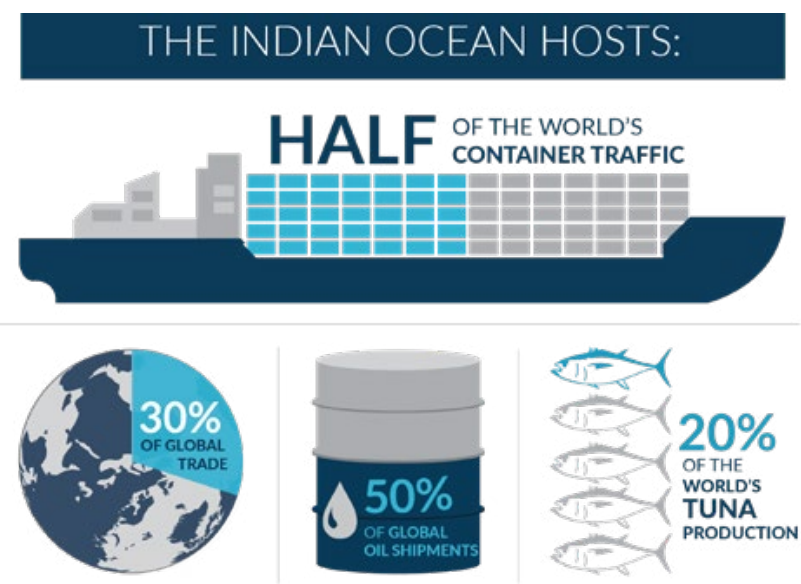
the world's largest consumers of fish, with annual per capita consumption of around $140 \mathrm{~kg}$. But illegal fishing, overfishing, and climate change have caused a reduction of major fish stocks within the region. In 2018 the Indian Ocean Tuna Commission (IOTC) conducted a stock assessment for yellowfin
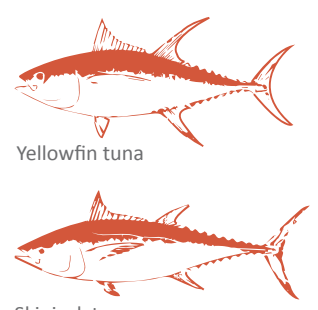

Skipjack tuna
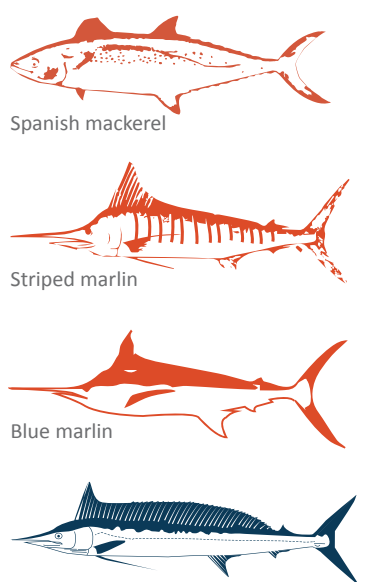

Indo-Pacific sailfish

IMPORTANT FISHING STOCKS IN THE INDIAN OCEAN (source: IOTC)

Overfished Overfishing Occuring tuna which determined that the species is drastically overfished and subject to overfishing. ${ }^{a}{ }^{2}$

The cause of the decline in stock status to below maximum sustainable yield is not well understood, but it has resulted in an urgent call for a reduction in yellowfin tuna catch to allow the species to recover. ${ }^{3}$ Similarly, the IOTC has determined that striped marlin, longtail tuna, and narrow-barred Spanish mackerel are both overfished, while overfishing is occurring for blue marlin and Indo-Pacific sailfish.

As Indian Ocean fish stocks have declined in recent years, there has been increased action to combat illegal fishing to ensure continued food and economic security in the region. In 2012, the European Union started the MASE program to enhance maritime security and combat illegal fishing. ${ }^{4}$ That same year, the FISH-i Africa Task Force was formed to aid in investigations of fisheries crime, improve the sharing of information and intelligence, and increase enforcement of laws against illegal fishing. ${ }^{5}$ In 2013 Project Scale was started as part of INTERPOL's work on environmental compliance and enforcement to "raise awareness of fisheries crime and its consequences." ${ }^{1}$ Just two years later, South Africa hosted the inaugural international symposium on FishCRIME, during which nearly 200 delegates represented 31 countries, all focused on combating illegal fishing. ${ }^{\text {? }}$

These efforts to curb illegal fishing led to the Jeddah Amendment to the Djibouti Code of Conduct in 2017, ${ }^{8}$ which broadened the scope of security coordination in the Indian Ocean and Horn of Africa region from a focus on piracy and armed robbery to include other illicit maritime activities, including illegal fishing.

And these actions just scratch the surface of recent work done to combat illegal fishing and other maritime crimes in the Indian Ocean. As an expansion of regional efforts to counter maritime piracy, 2018 saw both the Regional Maritime Information Fusion Center (RMIFC) and the Regional Coordination Operations Center (RCOC) increase staffing and their operational capabilities to process information and launch enforcement actions around illegal fishing and other maritime crimes.

a "Overfishing" occurs when more fish are caught than the population can replace through natural reproduction; in other words, when the rate of removal from stock is too high. When a fish population is too low, or below a prescribed threshold, it's considered "overfished." A population can be overfished but can be managed under a rebuilding plan that, over time, returns the population to optimal levels. 
However, despite the expansion of these regional engagement efforts, there is growing concern that most Indian Ocean states still lack the basic resources and capabilities needed to monitor their maritime domains and regulate maritime activities to prevent illegal fishing and ensure food security. Government agencies with mandates to address illegal fishing, such as fisheries departments, frequently lack the resources needed to combat it. And those agencies that have maritime resources, such as navies, are often not mandated to focus their efforts on illegal fishing.

This concern spurred a unique partnership between One Earth Future's (OEF's) Secure Fisheries program, the United Nations Office on Drugs and Crime's (UNODC's) Global Maritime Crime Programme, and US Naval Forces Africa (NAVAF) to conduct a series of workshops during 2018 in ten Indian Ocean states to advance interagency collaboration on illegal fishing and promote low-cost improvements for the collection of human intelligence on suspected illegal fishing vessels.

\section{There is growing concern that most Indian Ocean states still lack the basic resources and capabilities needed to monitor their maritime domains and regulate maritime activities to prevent illegal fishing and ensure food security.}

\section{History of Caught-Red Handed}

The collection of human intelligence is a valuable, though sometimes unrefined, tool for combating illegal fishing and associated maritime crime. Few resources are available to ensure that information gathered on vessels suspected of illegal fishing is collected in a standardized way; this undermines successful prosecutions of fisheries crime cases.

In response, Secure Fisheries and the UNODC assembled an Expert Working Group in February of 2017 to discuss strengthening human intelligence capabilities in the Indian Ocean to help combat illegal fishing. The working group consisted of maritime law enforcement agencies from Comoros, Kenya, Madagascar, Maldives, Mauritius, Seychelles, Somalia, Sri Lanka, and Tanzania. The Indian Ocean Commission, the Indian Ocean Tuna Commission, the World Bank, EUNAVFOR, and the Pew Charitable Trusts provided additional technical support.

The working group identified an urgent need to increase the value, sophistication, and standardization of human intelligence-gathering in the Western Indian Ocean. As a first step in meeting this need, the working group developed the Fishing Activity Sightings Checklist (Appendix 1), which systematically details information to be collected and analyzed when fisheries officers or other government personnel see or board a suspected illegal fishing vessel.

Secure Fisheries and the UNODC's Global Maritime Crime Programme then created an accompanying series of workshops, called Caught Red-Handed (CRH), which
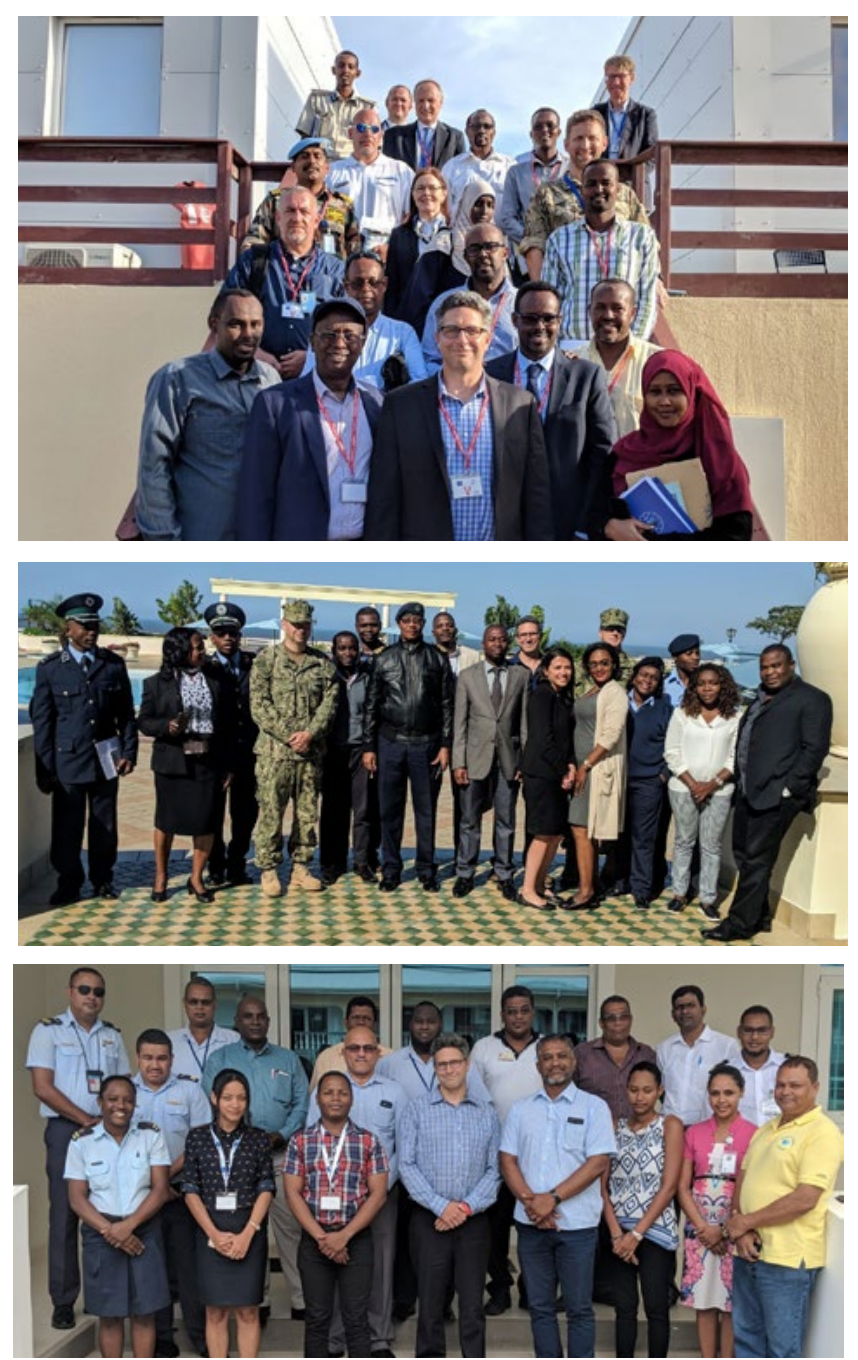

Participants at Caught Red-Handed workshops in Somalia, Mozambique, and Seychelles. 
focused on improving collection of and procedures for sighting data from various platforms including vessels, aircraft, and shore-based positions, as well as photo collection. The result was data standards and procedures that have been used by several Indian Ocean states and utilized as part of the Naval Forces Africa's Cutlass Express 19 exercise. ${ }^{9}$ The main goals of the Caught Red-Handed workshops were threefold:

1. improve the standardized collection of actionable human intelligence;

2. improve communication and dissemination of this intelligence; and

3. improve regional response to suspected cases of illegal fishing.

In addition to the workshops, the Caught Red-Handed project also worked with regional coordination bodies including the Regional Information Coordination Center in Mombasa, Kenya, and the Regional Maritime Coordination Centre in Victoria, Seychelles, toward accepting human intelligence as a reliable source of maritime domain awareness (MDA) information.

The Caught Red-Handed workshops were developed in collaboration with NAVAF and government representatives from Somalia, Seychelles, Comoros, Maldives, Kenya, Mauritius, Sri Lanka, Madagascar, Tanzania, and Mozambique.

In addition to this report, three briefs were created based on the results of the Caught Red-Handed workshop series:

1. Catching Maritime Criminals: A Whole-of-Government Approach explores how greater interagency coordination can solve a misalignment of mandates among government agencies.

2. Who's in your Backyard: Strengthening Maritime Domain Awareness in the Indian Ocean highlights five statebased solutions to increase maritime domain awareness and decrease illegal fishing in the Indian Ocean.

3. Maritime Security in the Indian Ocean: Perceived Threats, Impacts, and Solutions is based on surveys of more than 100 representatives from maritime agencies in ten Indian Ocean countries, and highlights perspectives about the most significant maritime security threats, the impacts of IUU fishing on human security and conflict, and the most effective approaches and needed resources for combating IUU fishing in each country.

\section{Goals of this Report}

In this report, we provide conclusions and their policy implications from the Caught Red-Handed project as a whole, while proposing three essential state-based actions to tackle illegal fishing. We also give an overview of the fisheries sector for each Caught Red-Handed country, detail their known and perceived levels of illegal fishing and their maritime human resources and agency coordination efforts, and summarize the recommendations that resulted from each country's workshop. Our goals for this report are to:

1. MEMORIALIZE THE RECOMMENDATIONS that each country's delegates put forward as part of the Caught Red-Handed workshop;

2. incorporate these recommendations into PROPOSED REGIONAL ACTIONS to fight illegal fishing in the Indian Ocean; and

3. STRENGTHEN THE POLITICAL WILL TO IMPLEMENT THE RECOMMENDATIONS of workshop delegates. 


\section{CONCLUSIONS AND POLICY IMPLICATIONS}

According to the International Maritime Organization, maritime domain awareness (MDA) is "the effective understanding of anything associated with the maritime domain that could impact security, safety, economy, or the environment."
Robust MDA is closely aligned with combating illegal fishing. But many Indian Ocean states lack sufficient resources-including patrol vessels, aircraft surveillance, satellite technologies, and personnel trained in fighting fisheries crimes - to successfully monitor for and respond to suspected illegal fishing activity. Caught Red-Handed delegates determined that in order to address this lack of MDA, Indian Ocean states must create a governmental framework that will ensure state-based maritime agencies are in close collaboration and coordination, and that these agencies are aligned with regional and international efforts to fight illegal fishing. But according to delegates, this has not happened in most states.
Caught Red-Handed workshop delegates called for a reprioritization of resources and improved coordination between fisheries and nonfisheries agencies to achieve better MDA and fight illegal fishing. Workshop delegates believe that the state agencies that have the most maritime resources, including patrol vessels, aircraft, and satellite capabilities, need stronger mandates to fight fisheriesrelated crime. Workshop participants also highlighted a problematic gap between agencies with capacity and agencies with illegal fishing-related mandates.

\section{Caught Red-Handed workshop delegates called for a reprioritization of resources and improved coordination between fisheries and non-fisheries agencies to achieve better MDA and fight illegal fishing.}

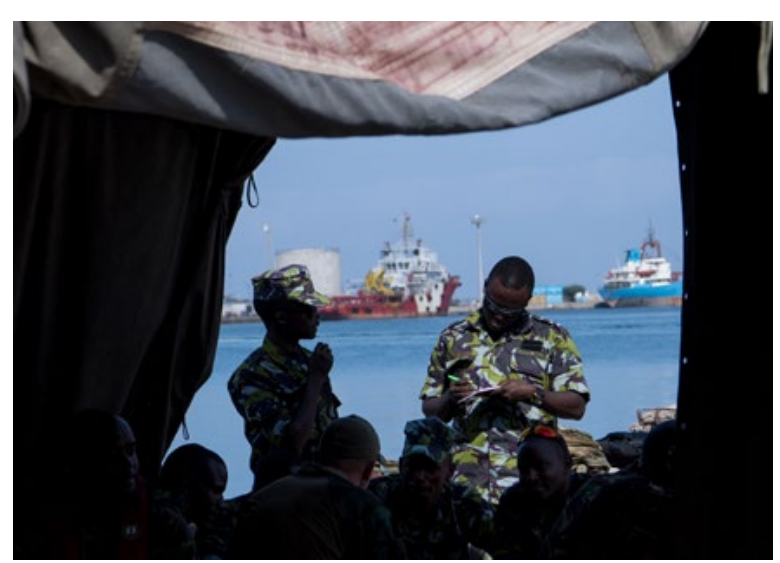

Members of the Kenyan navy prepare for a training exercise. The Kenyan navy is the only agency in Kenya with vessels that can operate beyond $12 \mathrm{~nm}$, but its mandate does not include combating illegal fishing. Photo: Staff Sgt. Amy Picard, US Navy.
For instance, Tanzania's marine police patrol territorial waters up to 12 nautical miles, while the navy is charged with securing and patrolling the rest of Tanzania's Exclusive Economic Zone (EEZ) out to 200 nautical miles from shore. The Tanzanian navy has ten boats of various sizes and capabilities and the marine police unit has four small boats. However, the Deep Sea Fishing Authority-the agency charged with fisheries management, licensing, and enforcement-currently has no vessels. ${ }^{10}$

Kenya faces a similar problem. The navy is the only Kenyan agency with vessels that can operate beyond 12 nautical miles, but the navy's national security mandate does not include combating illegal fishing. As a result, the Kenya Fisheries Service must rely on the navy for information collection and surveillance. Recently, the Kenya Fisheries Service obtained a patrol boat to monitor illegal fishing within the EEZ, but it is still being commissioned.

Even if navies have mandates to gather information on vessels suspected of illegal fishing, they still face gaps in knowledge and technical training that hinder their investigative capacity. ${ }^{11}$ As a result, vessels suspected of illegal fishing are often one step ahead of surveillance personnel. In Mozambique, navy participants discussed how challenging it is to recognize illegal fishing because suspicious vessels change their names and appearance and disable their vessel detection systems.

State agencies in the Caught Red-Handed workshops also identified the need for training in maritime investigations to extend beyond inspections for illegal fishing. As the complexity of maritime crimes increases, key maritime agencies 
say they are ill-equipped to conduct effective investigations. For instance, in Sri Lanka the navy is the lead agency in investigating human trafficking, drug smuggling, and illegal weapons trafficking, but they have had little coordination with the state's national police bureau, which has direct access to INTERPOL's global infrastructure of technical and operational support. Often this support is critical to an investigation's success. The ownership of illegal fishing vessels and the criminals themselves are frequently hidden behind complex networks of limited-liability companies, multinational crews, and "flag-of-convenience" states.

Caught Red-Handed states face significant challenges to combating illegal fishing and workshop participants emphasized the heavy toll illegal fishing takes on their economies and the livelihoods of artisanal fishers. Illegal fishing is something that many of them confront on a regular basis and have been fighting against for decades. This fight may seem futile for underfunded agencies vying for the vessels and technology to do their jobs. However, multiagency collaboration leverages the information and resources available to combat illegal fishing.

Caught Red-Handed provided a venue for collaboration and sharing information, but there is still much to be done. For Indian Ocean states to address maritime crime and conflict, illegal fishing must be prioritized, and agencies must be empowered with the resources and mandates to fight it. This report proposes three essential state-based actions:

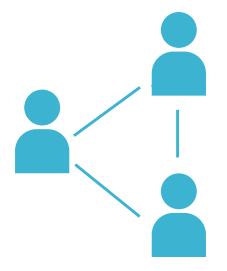

\section{ACTION 1: CREATION OF A COORDINATION TASK FORCE ON ILLEGAL FISHING}

This would be the primary national mechanism for information sharing, coordination, and collaboration between maritime agencies in the fight against illegal fishing. The task force would have representation from all maritime agencies, including but not limited to the ministry or department of fisheries, coast guard, navy, customs, ports, and prosecutors, and have a memorandum of understanding that outlines collective responsibilities. The task force would also be charged with interfacing with regional and international efforts to fight illegal fishing, such as efforts by the FISH-i Africa Task Force, the Regional Maritime Information Fusion Center in Madagascar, the Regional Coordination Operations Center in the Seychelles, the Program to Promote Regional Maritime Security, and the UNODC's Global Maritime Crime Programme.

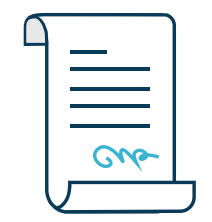

\section{ACTION 2: STRENGTHENING OF MANDATES AGAINST ILLEGAL FISHING FOR MARITIME AGENCIES}

All relevant maritime agencies should receive new or updated mandates that allow them to act on and prioritize illegal fishing. These proposed mandates would recognize that all maritime agencies have a role to play in fighting illegal fishing and would create a framework for effective interagency collaboration and coordination. These mandates would also ensure that maritime resources are used effectively in the collection of MDA, that agencies share information on suspected illegal fishing vessels, and that agencies work together toward successful prosecutions against illegal fishing.

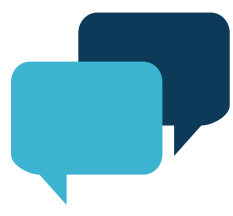

\section{ACTION 3: DEVELOPMENT OF POLICIES FOR SHARING INFORMATION ON ILLEGAL FISHING WITH EXTERNAL PARTNERS}

Maritime agencies are often hindered from sharing information because they lack a trusted network of peers and a way to securely exchange sensitive information, and have internal protocols that often prevent information exchange. Agencies charged with MDA and fisheries law enforcement should create policies and procedures for the sharing of information on illegal fishing with the Indian Ocean Tuna Commission, the Indian Ocean Commission, INTERPOL, the FISH-i Africa Task Force, the Regional Maritime Information Fusion Center, the Regional Coordination Operations Center, and other related entities that are working to combat illegal fishing. 


\section{SRI LANKA}

\section{Overview of Fisheries Sector}

Sri Lanka is an island country located southeast of India within the Bay of Bengal. It has a coastline extending 1,770 km and an EEZ that covers $517,000 \mathrm{~km}^{2}$, of which some $27,800 \mathrm{~km}^{2}$ form a continental shelf.

Sri Lanka's fisheries industry is a significant source of nutrition, food security, employment, and government revenue. Over the past several decades almost 2 percent ${ }^{12}$ of Sri Lanka's GDP has come from fisheries, while 60,000 people are employed, both directly and indirectly, in the fishing industry.

Sri Lanka's fishing fleet consists of about 50,000 boats, and while the majority of these are considered single-day fishing vessels, about 2,500 are large enough for multi-day use, including around 1,600 capable of high-seas fishing.

Fish contribute over 70 percent $^{13}$ of the animal protein consumed in Sri Lanka. And with a population expected to grow by 2.4 million people by 2050, Caught Red-Handed delegates saw the strengthening of fisheries management to be of paramount importance. According to workshop delegates, illegal fishing, overfishing, and bycatch are significant challenges to continued food security and sustainable livelihoods in Sri Lanka.

\section{Scope of Illegal Fishing}

Workshop delegates considered illegal fishing to be the single largest threat to maritime security in Sri Lanka, and a major obstacle to sustainable fisheries. A 2015 study showed Sri Lanka could lose an estimated \$336 million USD to illegal fishing each year. ${ }^{14}$ Also in 2015 , a report by the UN Food and Agriculture Organization's (FAO) Asia-Pacific Fishery Commission listed the Sri Lankan territorial waters in and around the Palk Strait as the fifth-largest illegal, unreported, and unregulated (IUU) fishing hotspot in Asia, ranked by both total landings and value. ${ }^{15}$

According to another FAO report, ${ }^{16}$ thousands of illegal trawlers from the Indian state of Tamil Nadu cross regularly into Sri Lanka and use damaging fishing methods such as bottom trawling to fish for shrimp and crab without any established rights to the fishery or permission from the Sri Lankan government.

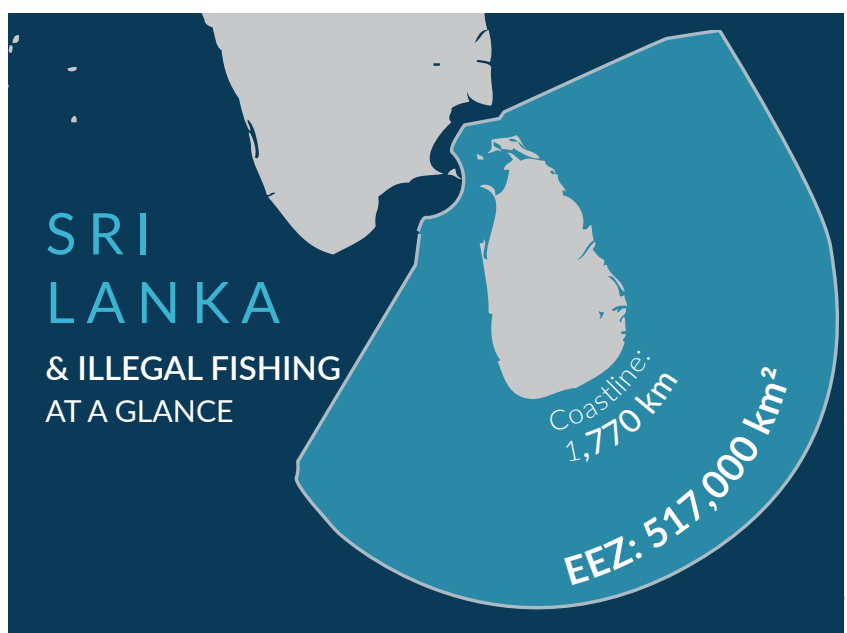

\section{FISHERIES SECTOR:}
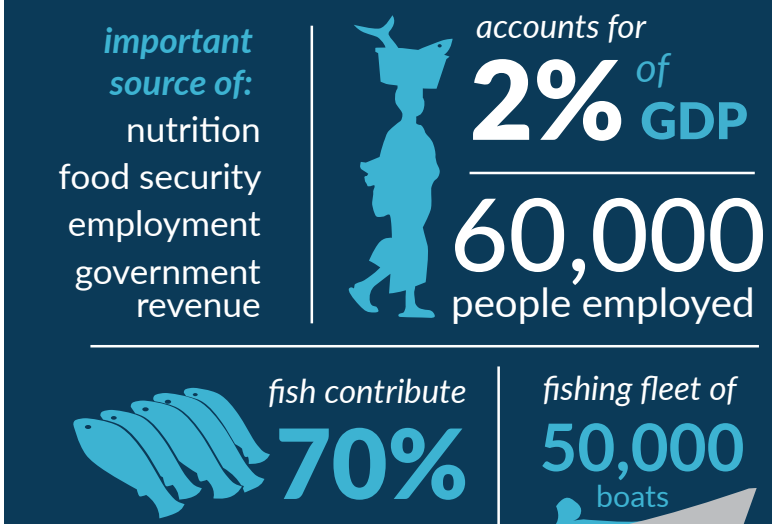

of animal protein consumed fishing fleet of 50,000

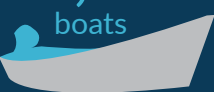

\section{CHALLENGES:}

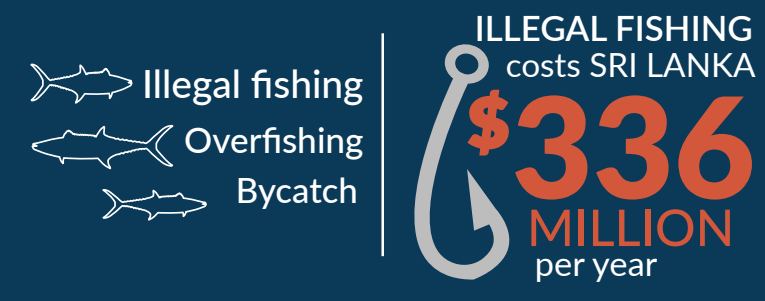

\section{MARITIME AGENCIES COMBATING ILLEGAL FISHING:}
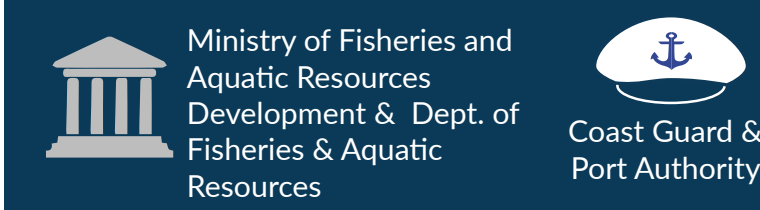

Coast Guard \& Port Authority 
In the past, Sri Lankan policies enabled illegal fishing. In 2014 Sri Lanka was "red-carded" by the European Commission, ${ }^{17}$ which identified the country as a "non-cooperating third country" on the basis that they were not taking enough action to prevent, deter, and eliminate illegal fishing. This resulted in a ban on importing raw and processed fish from Sri Lanka to the EU.

The red card and the ban were lifted ${ }^{18}$ in the first half of 2016 in recognition of the efforts made by the government to address illegal fishing. Some of these efforts included increasing fines ${ }^{19}$ by over 100 times on illegal foreign vessels to deter them from fishing in the Sri Lankan EEZ. This increase was part of a bill that amended Sri Lanka's Foreign Fisheries Boats Regulation Act. However, it is difficult to tell if this has resulted in a decrease in illegal fishing in Sri Lanka.

According to Caught Red-Handed delegates, illegal fishing is also related to other maritime crimes in Sri Lanka, such as drug smuggling and piracy. Illegal fishing has a considerable influence on political, economic, military, societal, and environmental security in the context of the national security of Sri Lanka. ${ }^{20}$ For example, in the mid-1980s the issue of poaching between Sri Lanka and India came to the forefront with the emergence of violent ethnic conflict between the Tamil militants and the Sri Lankan government.

Poaching continues today with trespassing by fishermen from both Sri Lanka and India, mostly around the Palk Strait, Palk Bay, and Gulf of Mannar. According to Caught Red-Handed delegates, fishers from both countries rarely respect the maritime boundaries because the earnings from fishing are far more important to them than the costs associated with getting caught.

\section{Maritime Human Resources and Interagency Coordination}

Administratively, Sri Lanka's efforts to combat illegal fishing are led by the Ministry of Fisheries and Aquatic Resources Development and the Department of Fisheries and Aquatic Resources (DFAR), and interdiction of illegal fishing vessels is handled by the Sri Lanka Coast Guard and Port Authority. The coast guard has several patrol vessels, but only one-the Suraksha, commissioned in 2017-is capable of patrols beyond coastal waters. Beginning in 2013, due to the increase in the number of multi-day fishing boats, Sri Lanka expanded their fisheries management mandate to include Sri Lankan vessels operating outside their EEZ.

According to Caught Red-Handed workshop participants, Sri Lanka has several other traditional and non-traditional maritime agencies that can assist the government in fighting illegal fishing, including the army, air force, police, customs department, and prosecutor's office. But workshop delegates stressed that very little collaboration or coordination occurs between both the traditional and the non-traditional maritime agencies. To aid in interagency coordination, the High Seas Fisheries Unit was established by the DFAR in 2018 as an institutional arrangement supporting monitoring, control, and surveillance (MCS) of Sri Lanka's EEZ.

The logbook data for all vessels in Sri Lanka are now managed by the High Seas Fisheries Unit. They also play a significant role in supporting the collection and analysis of vessel monitoring system (VMS) data. The unit analyzes VMS alerts, conducts investigations on suspect vessels, and provides support for legal action against any vessel found to be engaging in illegal fishing.

The Investigation Unit of DFAR also provides institutional support on illegal fishing investigations by:

- analyzing and investigating VMS alerts and cruise track data provided by the High Seas Unit;

- investigating vessel departures without approvals;

- investigating suspect logbook entries or logbook records provided by fisheries inspectors; and

- proceeding with legal actions against illegal fishing activities and the violation of fisheries regulations. 


\section{Workshop Recommendations}

The Caught Red-Handed workshop in Sri Lanka took place on May 24-25, 2018, and was attended by senior staff from Sri Lanka's Department of Fisheries, Attorney General's Department, and Coast Guard. In addition, 48 members of the Sri Lanka Navy were in attendance, as was the former Sri Lankan representative to the United Nations.

The delegates continued to identify interagency collaboration as one of the main roadblocks to combating illegal fishing, even with the High Seas Fisheries Unit in place. The delegates also discussed the best ways to strengthen interagency collaboration in order to collect and process information on suspect illegal fishing vessels and ensure successful prosecution. This resulted in:

1. IDENTIFYING KEY AGENCY STAKEHOLDERS in the collection of information and intelligence on illegal fishing vessels;

2. recommending the CREATION OF BOTH NATIONAL AND LOCAL-LEVEL INTERAGENCY TASK FORCES which would be dedicated to illegal-fisheries-related information collection and sharing; and

3. IDENTIFYING KEY AGENCY FOCAL POINTS for the collection, analysis, and communication of intelligence on illegal fishing. 


\section{MALDIVES}

\section{Overview of Fisheries Sector}

The Republic of Maldives is an archipelagic country of 1,190 islands in the Indian Ocean, with an EEZ covering 859,000 $\mathrm{km}^{2}$ and 26 atolls. Around 200 islands are inhabited; 140 islands are used exclusively as tourist resorts, and the rest of the islands are uninhabited and used mostly for industrial and agricultural purposes. ${ }^{21,} 22$ The country has a population of about 400,000 people. ${ }^{23}$

The Maldives relies on coastal and marine resources for subsistence and its economic development. The fisheries sector plays a critical role in food supply, ${ }^{24}$ as tuna is the primary source of protein in the local diet. According to the $\mathrm{FAO}$, average fish consumption per capita is $140 \mathrm{~kg}$ per person per year, with $94 \mathrm{~kg}$ coming from tuna.

Fisheries also provide a means of livelihood for over 20 percent of Maldivians. About 2,626 villages rely on fisheries as their main income source, including indirectly from working in maritime industries such as boatbuilding, ice production, fish processing, trading and marketing, and fishing vessel maintenance. ${ }^{25}$ The tuna fisheries sector is a driver of economic growth and development, with close to 20,000 formal and informal fishers.

Fisheries account for 6 percent of GDP, 11 percent of employment, and 98 percent of the country's export commodities. And though fisheries' contribution to GDP has shown a continual declining trend since 1978, this has mainly been caused by the introduction and rapid growth of the tourism sector and the diversification of fisheriesrelated businesses into other economic sectors such as export and labor.

Maldivian tuna fishery uses mostly pole-and-line, handline, longline, and troll line fishing methods. ${ }^{26}$ The most important is the traditional live-bait pole-and-line tuna fishery, targeting primarily skipjack tuna and smaller amounts of bigeye and juvenile yellowfin tuna.

\section{Scope of Illegal Fishing}

The delegates from the Caught Red-Handed workshop in the Maldives considered illegal fishing to be their biggest maritime threat and a major obstacle to sustainable fisheries management. This concern is backed up by the Maldives

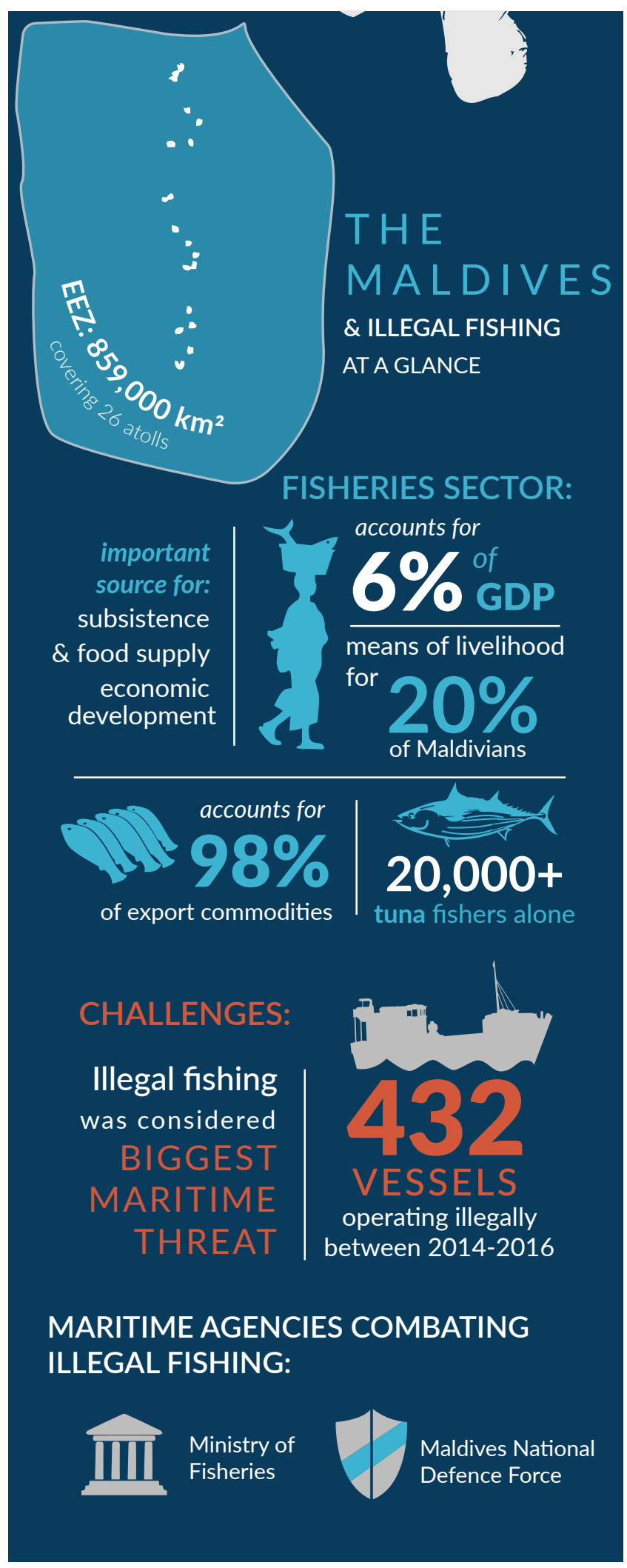


Ministry of Fisheries and Agriculture, which commissioned a study that found 432 foreign fishing vessels operating without the required permits or licenses between the years 2014 and 2016. ${ }^{27}$ This assessment, conducted using AIS data, also identified 542 unauthorized buoys deployed or drifting through Maldivian waters.

Moreover, in 2018 there were several high-profile illegal fishing incidents in the Maldives, including the following.

- In January 2018 two Somali-flagged fishing vessels, FV Chotpattanna 55 and FV Chotpattana 51, were apprehended with 10 and 12 Thai crew members, respectively. Each vessel had approximately 200 tons of illegally caught fish. ${ }^{28,} 29$

- In November 2018 the Maldives Coast Guard intercepted and seized two illegal Sri Lankan fishing vessels fishing in Maldivian waters, along with 10 Sri Lankan crew members.

In December 2018 the Sri Lankan vessel FV Oshadi 1 was caught illegally fishing and carrying about a ton of fish, mostly shark. ${ }^{30}$ Shark fishing was banned in the Maldives in 2010 and the vessel's six crew members were arrested by the coast guard.

\section{Maritime Human Resources and Interagency Coordination}

Several government departments are responsible for ensuring the sustainable use of marine and coastal biodiversity in the Maldives, including the Ministry of Environment and Energy; Ministry of Economic Development; Ministry of Fisheries, Marine Resources, and Agriculture; and the Local Government Authority. The Maldives' efforts to combat illegal fishing are led by the Ministry of Fisheries and the Maldives National Defence Force (MNDF).

\section{Workshop Recommendations}

The Caught Red-Handed workshop took place on the island of Malé on May 28 and 29, 2018, and was attended by senior staff from the coast guard (part of the MNDF), the Maldives Attorney-General's Office, the Maldives Prosecutor-General's Office, the Maldives Police Marine Operations Unit, and the Maldives Customs Service.

The delegates recognized the need to strengthen interagency collaboration in order to increase the collection and processing of information on suspected illegal fishing vessels. Workshop participants discussed collaborative ways to collect, store, analyze, and share fishing vessel information, resulting in the following four recommendations:

1. DEVELOPMENT OF A NATIONAL MARITIME INTELLIGENCE BUREAU in the Maldives;

2. DEVELOPMENT OF A JOINT INTERAGENCY WORKING GROUP on illegal fishing;

3. DEVELOPMENT OF A MARITIME FUSION CENTER, which will have MDA capabilities; and

4. CLOSER COORDINATION WITH THE INDIAN OCEAN MARITIME FUSION CENTERS to share information on suspected illegal fishing and other maritime crimes.

Additionally, delegates discussed the establishment of a joint operations center to fight illegal fishing and a system for sharing information with international stakeholders. 


\section{KENYA}

\section{Overview of Fisheries Sector}

The Republic of Kenya straddles the equator and encompasses a portion of the Indian Ocean and Lake Victoria. Kenya's marine coastline is over $640 \mathrm{~km}$ long, with an EEZ of $114,337 \mathrm{~km}^{2}$. The country has varied marine habitats, including deep oceanic waters that support productive ecosystems. ${ }^{31}$ Kenya has an almost continuous fringing coral reef which stretches parallel to the coast.

Kenya's marine fisheries are critical to food security and livelihoods for coastal communities. ${ }^{32}$ Average per capita fish consumption (including marine, freshwater, and aquaculture) in Kenya is about $5 \mathrm{~kg}$ per year. ${ }^{33}$ Additionally, Kenya's fisheries and aquaculture sector contributes approximately 0.54 percent to the country's GDP. ${ }^{34}$ The value of fish exports was about $\$ 63$ million in 2012, about five times greater than fish imports. It is estimated that around 13,000 people derive their livelihoods from marine fisheries, compared to 48,300 for inland fisheries and around 67,900 from fish farming. ${ }^{35}$

Coastal fisheries are mainly artisanal and subsistence, and are undertaken mostly from small, non-motorized boats such as outriggers, dhows, and "planked pirogues." Kenya's entire artisanal fishing fleet consists of 3,500 small-scale, mostly wooden crafts usually used for single-day fishing trips. Additionally, in 2017 an estimated 414 artisanal vessels were engaged in extended fishing trips, targeting tuna and tunalike species while using longline hooks, gillnets, monofilament nets, and artisanal trolling lines. ${ }^{36}$

Kenya's offshore fisheries are mostly exploited by distant-water fishing nations including the Seychelles, Mayotte, Spain, France, and Taiwan Province of China, with a focus on skipjack, yellowfin, and bigeye tuna. The FAO has reported licenses for 33 purse seiners and 30 longliners, while Kenya's State of the Coast report states that 19 and 34 licenses were active in 2008 and 2010, respectively. ${ }^{37}$ The Sea Around Us Project, however, has reported a much higher figure, stating that 116 vessels were licensed to fish in 2015. ${ }^{38}$ Definitive numbers have been difficult to obtain.

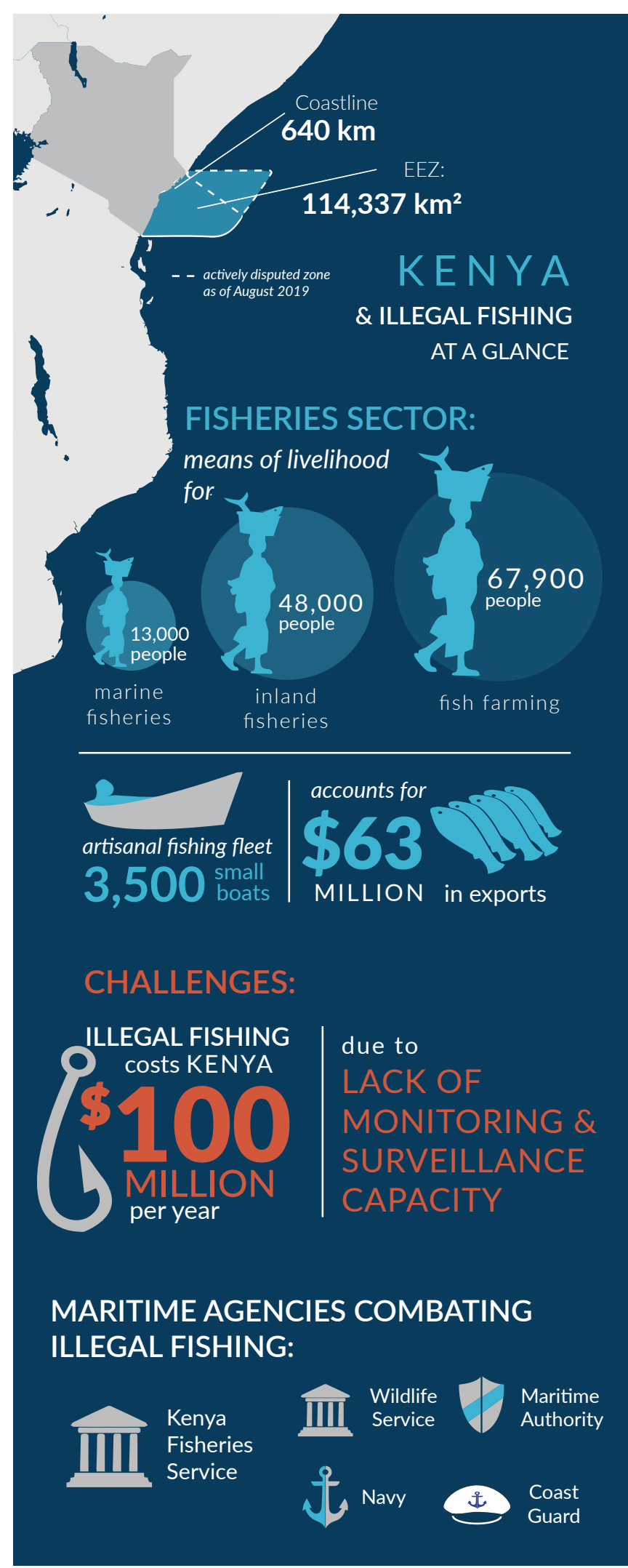




\section{Scope of Illegal Fishing}

Kenya loses an estimated $\$ 100$ million annually due to illegal fishing activities in its EEZ ${ }^{39,40}$ and, according to Caught RedHanded delegates, the lack of monitoring and surveillance capacity is thought to be a major reason.

Workshop delegates highlighted many challenges in fighting fisheries crimes in Kenya, including inadequate experience in MDA and insufficient resources to enable fisheries officers to investigate, properly gather, collect, or preserve evidence that meets standards for prosecution and conviction of offenders. The efficacy of fisheries-crime-related law enforcement is undermined by inadequate capacity, training, and technical skills and expertise in fisheries law enforcement. Thus, workshop delegates expressed the need for additional training and capacity building so officials can better detect fisheries crimes, identify relevant species, carry out investigations, and gather evidence to successfully prosecute the accused.

Kenya also lacks adequate technological resources to enable monitoring and surveillance of the activities of fishing vessels in its coastal waters, especially for Kenya's distant-water fishing fleet. ${ }^{41}$ There is also limited awareness on the impacts of fisheries crimes and fisheries offenses, which results in penalties that are often administrative in nature with low fines imposed.

According to John Karungo from the Kenya Fisheries Service, there has never been an arrest of an illegal fishing vessel in Kenya's offshore waters. Karungo believes this is because historically the Kenyan navy lacked the necessary capacity and information to inspect and apprehend illegal fishing vessels. In 2018 this led to the creation of the Kenya Coast Guard Service, which focused their efforts on enforcement matters, allowing the navy to concentrate on safeguarding the sovereignty and integrity of the Kenyan EEZ.

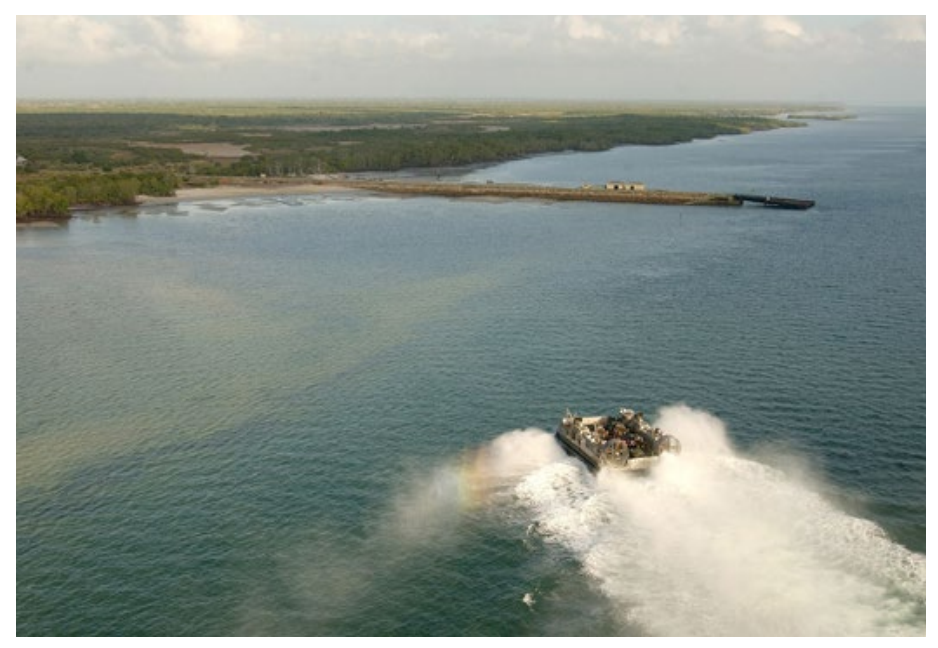

A landing craft cushion heads towards Manda Bay Kenyan Naval training area. Photo: Ted Banks, US Navy photo.

And this recent focus on enforcement has led to more detentions. In June 2018, 109 Tanzanian fishers were detained for engaging in illegal fishing within Kenya's territorial waters off Shimoni. ${ }^{42}$ In November 2018, 16 Tanzanian fishermen were briefly detained by Kenyan Beach Management Unit officers and accused of illegal fishing. ${ }^{43}$ And in December 2018, 26 Tanzanian and 13 Kenyan fishers were charged with using illegal fishing nets. The fishers were found with 758 pounds of fish allegedly caught using illegal nets. ${ }^{44}$

\section{Maritime Human Resources and Interagency Coordination}

The Kenya Fisheries Service is the primary agency responsible for fisheries management in Kenya. The principal legal instrument applied by the service is the Fisheries Management and Development Act 2016 and its various subsidiaries. In fighting illegal fishing, the fisheries service is aided by the Maritime Police Unit, the Kenya Wildlife Service, the Kenya Maritime Authority, the Kenyan navy, and the new Kenya Coast Guard Service.

The Kenya Coast Guard Service is a multi-agency security agency established under the Kenya Coast Guard Service Act of 2018 to enforce law and order in Kenya's territorial waters. One of the main targets for patrols will be foreign fishing vessels trawling in Kenyan waters ${ }^{45}$ Apart from stopping illegal fishing, the coast guard will also be tasked with combating drug trafficking, piracy, the smuggling of contraband goods, the degradation of the marine ecosystems through the dumping of oil and toxic waste, and the destruction of coral reefs. ${ }^{46}$ Currently Kenya's coast guard has only one boat, the MV Doria; thus the new force still relies heavily on the navy for patrols. 


\section{Workshop Recommendations}

The Caught Red-Handed workshop in Mombasa, Kenya, took place on July 9-10, 2018, and was attended by representatives from the Kenya Maritime Police Unit, Kenya Fisheries Service, Kenya Wildlife Service, Kenya Maritime Authority, INTERPOL, Vulcan Inc., and the United States Navy.

Much of the discussion focused on the best ways to strengthen interagency collaboration in order to collect and process information on vessels suspected of fishing illegally. The workshop generated the following four recommendations.

1. THE FISHING ACTIVITY SIGHTING CHECKLIST SHOULD BE USED by every group involved in the maritime space to increase MDA in Kenya's EEZ. This information should be collated and conveyed to the Kenya Navy, the Kenya Coast Guard Service, and the Kenya Fisheries Service.

2. A FOCUSED MULTI-AGENCY COORDINATION TASK FORCE should be set up to fight illegal fishing, potentially under the Joint Operations Centre.

4. The multi-agency coordination task force should ESTABLISH PROTOCOLS AND RECEIVE FURTHER TRAININGS on information gathering, analyzing, and sharing.

5. The significance of ILLEGAL FISHING SHOULD BE EMPHASIZED TO HIGHER-LEVEL

DECISIONMAKERS. Potential decision-making stakeholders include the Blue Economy Committee, the Court Users Committee monthly forum, the Director of Public Prosecutions, and policymakers. 


\section{MOZAMBIQUE}

\section{Overview of Fisheries Sector}

Mozambique has a coastline that extends $2,770 \mathrm{~km}$ along the southeastern edge of the African continent and an EEZ of $562,000 \mathrm{~km}^{2}{ }^{27}$ The fisheries sector is an important source of employment, income, and food for the country. ${ }^{48}$ Fisheries production has risen from 290,915 metric tons in 2015 to an estimated 394,000 metric tons in 2018, accounting for 10.3 percent of Mozambique's GDP. ${ }^{49}$ Most of this growth has come from small-scale, artisanal fishers who account for 92 percent of the total catch, with the rest coming from industrial and semi-industrial fishing boats.

The industrial fishing sector is dominated by shallow-water shrimp trawling and deep-water crustacean trawling. Foreign distant-water fishing nations are the main group fishing for tuna and tuna-like species, with 23 longliners and 7 purse seiners authorized to fish in the Mozambique EEZ in 2017. ${ }^{50}$

A fisheries agreement has been in place with the European Union which allows vessels mainly from France, Spain, Portugal, Italy, and the UK to fish in Mozambican waters. ${ }^{51}$ There is also an access agreement with Japanese fishing companies, and in 2018 there were news reports ${ }^{52}$ that six Chinese vessels owned by the Yu Yi Industry Company were operating in Mozambique's waters, but this could not be confirmed.

About 187 industrial vessels are also operating in domestic fisheries. The main commercial species targeted by this sector include lobster, crabs, gamba (deep-water shrimp), fish, shallow-water shrimp, crayfish, and squid.

The small-scale and artisanal fisheries in Mozambique play a significant role in the national economy, and consist of individuals or small groups of fishers. They make use of nonmotorized fishing vessels between three and eight meters in length and use beach seines, gillnets, and longlines to catch fish. This sector also consists of fish collectors and divers. It is estimated that the number of fishing boats and canoes is approximately 15,000, with only 3 percent equipped with engines. Most of the fish harvested by artisanal fishers are for subsistence or are distributed close to the landing sites. Very little of the artisanal catch is exported, with the exception of shrimp.

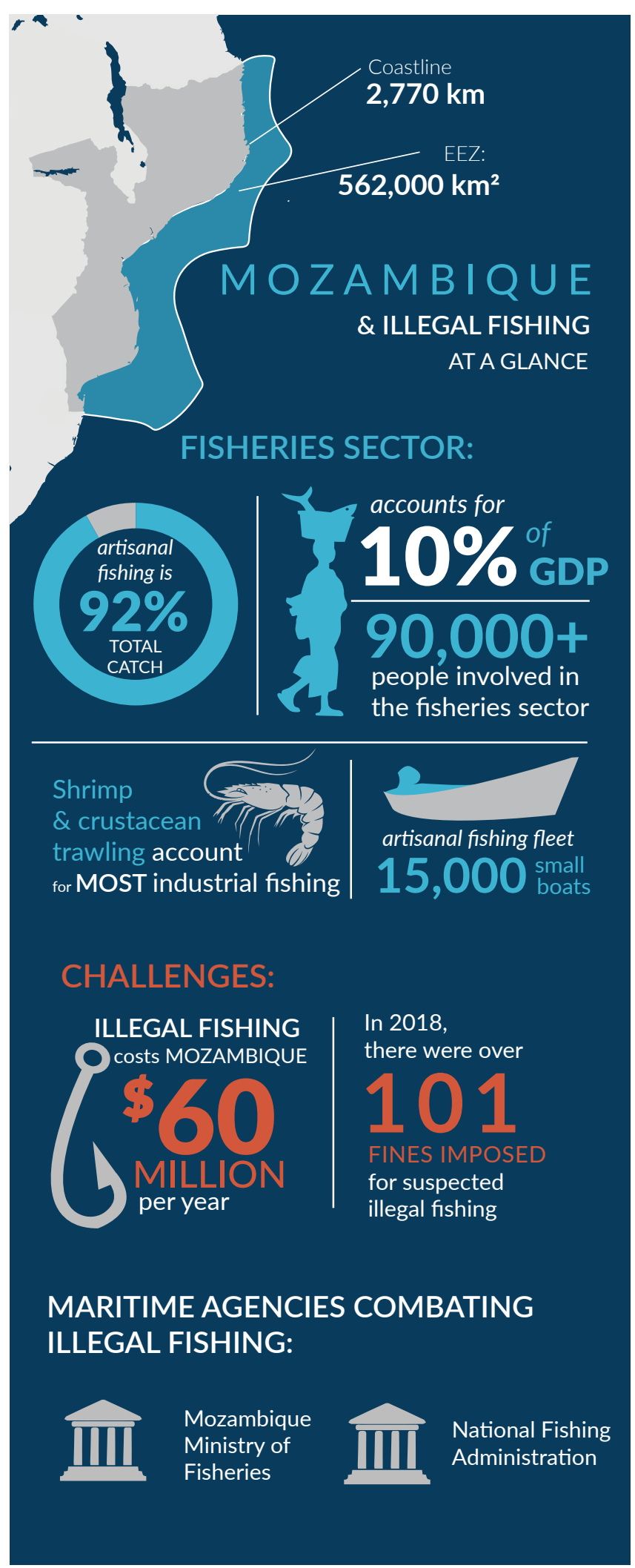


More than 90,000 people are involved in the fishing sector (including fishing, gathering, processing, and marketing), of which around 70,000 are involved in the marine sector and 20,000 in the freshwater sector. ${ }^{53} \mathrm{It}$ is estimated that about 500,000 people depend on fisheries for their livelihood. In addition, fisheries contribute 13 percent of Mozambique's export income, with foreign trade characterized by exports of high-value tuna products and imports of lower-value fish. ${ }^{54}$

Mozambique's average fish consumption per capita is estimated at $5 \mathrm{~kg}$ annually; however, it is much higher among coastal communities, where it is estimated to be between $10-12 \mathrm{~kg}$ annually. ${ }^{55}$

\section{Scope of Illegal Fishing}

Little information is available on the status of illegal fishing in Mozambique, but it has been estimated that the country loses at least $\$ 60$ million annually. ${ }^{56,57}$

Some of Mozambique's higher profile illegal fishing arrests include the following.

- In 2008 the government confiscated the Antillas Reefer, a Namibian-flagged fishing vessel, for fishing illegally. ${ }^{58}$ When the Antillas Reefer was inspected in Maputo, 43 tons of sharks, 4 tons of shark fin, 1.8 tons of shark tail, 11.3 tons of shark liver, and 20 tons of shark oil were allegedly found on board. The total value of the catch was estimated at around $\$ 600,000$.

- In 2016 Mozambican authorities confiscated the fishing vessel Nessa 7 for fishing illegally..$^{59}$ In addition, the owner, Anthony Rowan Pentz, was ordered to pay a fine of $\$ 94,000$, while the captain was banned from fishing in Mozambican waters for 36 months. The vessel entered Mozambican waters without any communication or prior authorization. Moreover, it was hiding identity marks, possessed gear for longline fishing of tuna, and wasn't displaying any flag or registration number. When taken into the port of Maputo, the identity of the Nessa 7 was established to have formerly been the Naham 4, bought by Pentz from the South African authorities following the vessel's seizure in 2013 for operating on false documents and being linked to a significant case in which up to five vessels were thought to be operating and fishing using one identity.

- In 2018 Mozambique confiscated the Seychelles-registered longline vessel Ocean Storm for illegal fishing and fined the captain $\$ 65,000 .^{60}$ The vessel was flagless, and had no identification number nor any normal fishing or navigation logs. When it was approached, the ship tried to escape, but was pursued and seized. Ocean Storm did not report its position when it entered Mozambican waters, and had no license to fish in Mozambique.

In 2018 there were over 700 inspections of commercial fishing vessels, with 101 fines imposed for suspected illegal fishing. ${ }^{61}$ These fines amounted to about $\$ 1.3$ million.

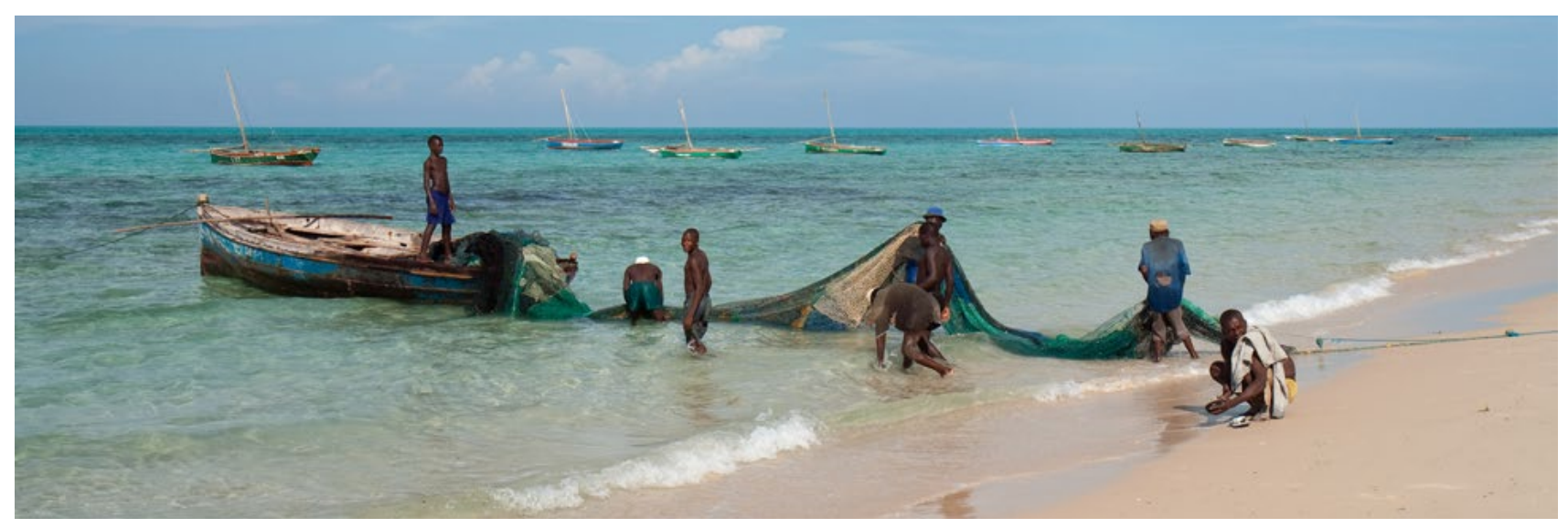

Artisanal fishing near Nampula, Mozambique. Photo: Stig Nygaard. 


\section{Maritime Human Resources and Interagency Coordination}

Mozambique's Ministry of Fisheries is charged with combating illegal fishing. And while the ministry has policies and procedures for boarding vessels suspected of illegal fishing, Caught Red-Handed delegates said that these procedures are currently not communicated with other groups involved in ports, including navy, customs, and maritime police. Moreover, the ministry is responsible for information collection, but oftentimes this information does not reach other agencies.

The National Fishing Administration currently manages information and analysis regarding fishing and fishing vessels. Fishing vessel information, primarily VMS information, is currently shared ad hoc via email, phone, letters, and personal communication.

To aid the ministry in MDA, the Southern African Development Community (also known as SADC) is setting up a Regional Fisheries Monitoring, Control and Surveillance center in the outlying Maputo neighborhood of Katembe. ${ }^{62,63}$

\section{Workshop Recommendations}

The Caught Red-Handed workshop took place in Maputo on July 12-13, 2018. Representatives from the Mozambique Ministry of Sea, Inland Waters and Fisheries; Mozambique Coastal, Lake, and River Police; National Marine Institute; Port of Maputo; Mozambican navy; and Inhambane Provincial Directorate of the Inland Sea and Fisheries attended, as well as United States Drug Enforcement Administration and United States Embassy representatives.

According to Caught Red-Handed delegates, in cases of illegal fishing, the vessel is confiscated and the commander is reported to other countries. But the delegates stressed that Mozambique needs increased interagency collaboration on illegal fishing because such activity is associated with other crimes, including drug trafficking. In order to achieve increased collaboration, the delegates recommended:

1. the ESTABLISHMENT OF A MARITIME COORDINATION CENTER with representatives from each maritime agency;

2. a FISHING VESSEL DATABASE that should be stored and analyzed at the newly formed coordination center;

3. PROACTIVE COOPERATION between all relevant maritime agencies;

4. exploration of the possibility of INCLUDING THE PRIVATE SECTOR IN THE INFORMATIONGATHERING PROCESS; and

5. LAW REFORM so that illegal fishery will be mentioned in the penal code. 


\section{TANZANIA}

\section{Overview of Fisheries Sector}

Tanzania's EEZ has an area of $223,000 \mathrm{~km}^{2}$ and a coastline that stretches $1,424 \mathrm{~km}$, including Zanzibar and the Pemba Islands. ${ }^{64}$ Marine fishing is predominantly inshore, as the continental shelf off the coast is relatively narrow; in most places it is only 8 to $10 \mathrm{~km}$ wide, but it extends about $40 \mathrm{~km}$ off the shore of the islands of Zanzibar and Mafia. ${ }^{65}$

Marine fisheries in Tanzania occur both inshore in territorial waters and offshore, extending to the edge of the EEZ. Inshore fisheries mainly target shrimp, lobster, cephalopods, and crabs, and offshore industrial fisheries generally target tuna, tuna-like species, marlin, swordfish, and sharks. ${ }^{66}$

Tanzania's artisanal fishers typically use outrigger canoes or small dhow-type planked boats (mashua) to access fishing grounds. In 2006 there were an estimated 7,190 active vessels, with smaller boats using mostly gillnets and shark nets, and larger semi-industrial vessels using larger weighted nets from trawlers. ${ }^{67}$

Outside of territorial waters, larger purse seine and longline vessels target tuna and tuna-like species, including marlin, swordfish, and sharks. The offshore fishery is solely industrial, and the bulk of the catch is exported. ${ }^{68}$

Tanzania's fisheries production has been in the range of 325,000 to 380,000 metric tons annually, with about 14 percent coming from marine fisheries, as 85 percent comes from inland fisheries and 1 percent from aquaculture. ${ }^{69}$ Overall per capita fish consumption in Tanzania is estimated to be about $7-8 \mathrm{~kg}$ per year, accounting for about 30 percent of the total animal-protein intake in the country.

In 2014 , there were some 183,800 persons engaged in fishing, accounting for about 0.7 percent of the workforce, with a large but unknown number also engaged in fish trading and processing. Fisheries contribute about 2.4 percent to Tanzania's GDP.

As of 2016, there were three large Tanzanian-flagged tuna longliners (between 44 and 49 meters long) registered in Zanzibar and operating throughout the Indian Ocean. There are also several foreign fishing vessels licensed to operate in the Tanzanian EEZ from Seychelles, South Korea, France, and Spain, but the number of licenses has fluctuated significantly from between zero in 2011 and 2012 to 74 in 2014. ${ }^{70}$

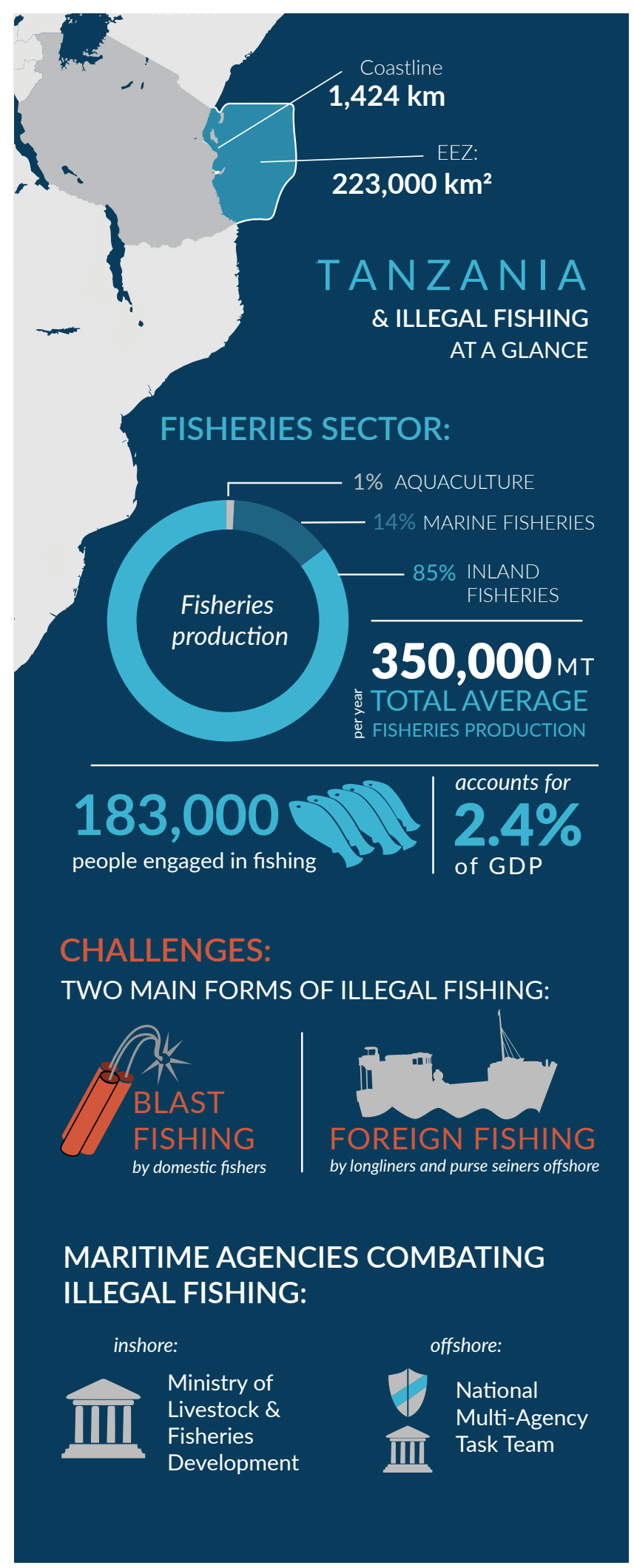



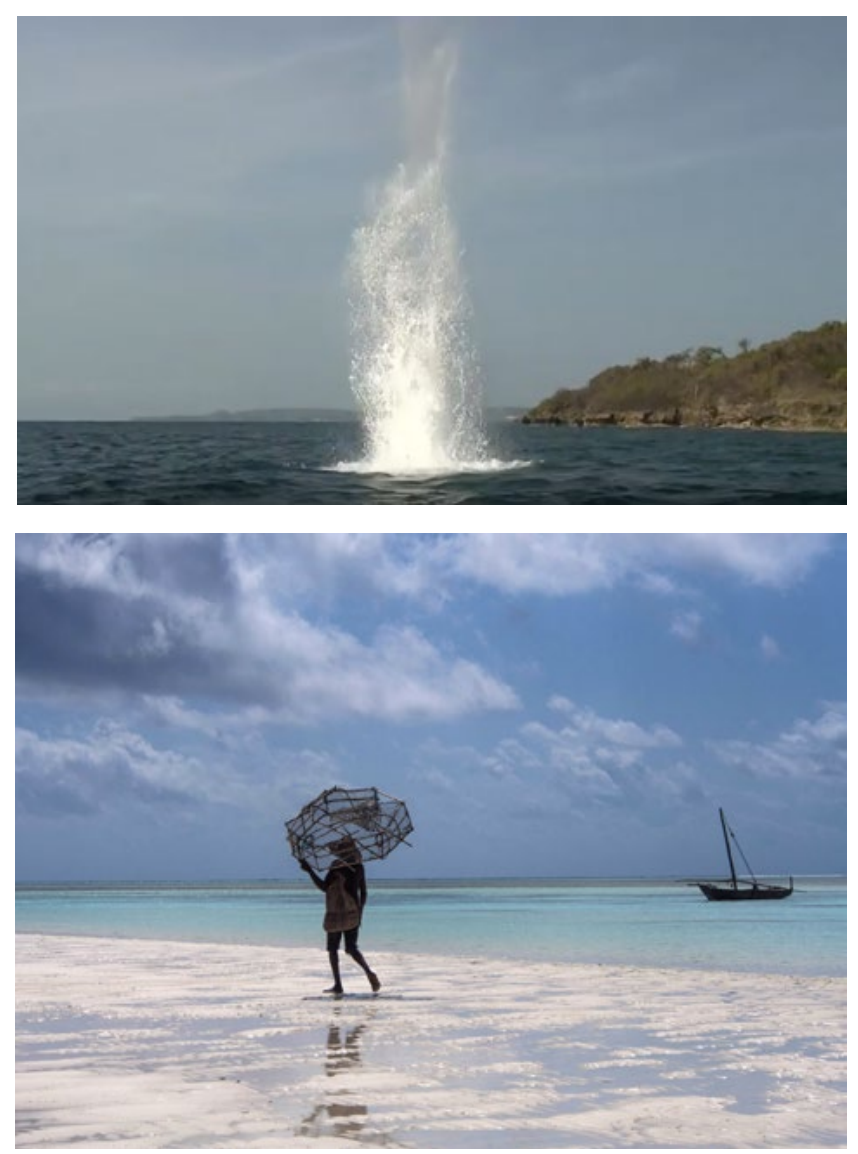

Top: A blast from illegal dynamite fishing in Tanzania. Photo: WorldFish.

Bottom: Carrying a trap on the beaches of Zanzibar. Photo: Georgie Pauwels.

\section{Scope of Illegal Fishing}

Though there are no reliable statistics available to quantify illegal fishing in Tanzanian waters, Caught Red-Handed participants discussed two main forms of illegal fishing in maritime areas. The first is from blast fishing by the domestic fleet, also called dynamite fishing, which occurs in inshore areas and destroys large numbers of fish and coral reefs. The second is illegal fishing by foreign longliners and purse seiners, which occurs mostly offshore. ${ }^{71}$

To combat illegal foreign fishing, a partnership was formed in 2018 between the Tanzanian government, the FISH-i Africa Task Force, and Sea Shepherd. Operation Jodari, a multi-agency task force from the Tanzanian government, was stationed on board the MV Ocean Warrior with Sea Shepherd crew members. Operation Jodari provided an opportunity to increase patrols and ensure compliance with national and international regulations. ${ }^{72}$ During the operation, three vessels were impounded for fishing illegally and ten arrests were made.

In a few instances, evidence of shark finning was found on the vessels, with detached fins on board in contravention of Tanzanian regulations and the IOTC's conservation and management measures. In another instance, juvenile dolphins that were prepared for export were discovered on the FV Buah Naga No. 1. Operation Jodari also led to a $\$ 50,000$ fine being paid to Tanzania's Deep Sea Fishing Authority by the owners of longliner FV Jin Sheng No. 2 for refusing an inspection and for the mistreatment of their crew.

\section{Maritime Human Resources and Interagency Coordination}

Inshore fisheries in Tanzania's 12-nautical-mile territorial sea are managed by the Ministry of Livestock and Fisheries Development, while offshore fisheries beyond 12 nautical miles are managed by the Deep Sea Fishing Authority. In 2015 Tanzania launched a National Multi-Agency Task Team charged with combating illegal fishing and other environmental crimes ${ }^{73}$ The team is led by the Tanzania Police Force and includes the Tanzania Forest Service, Tanzania Wildlife Division, Tanzania Fisheries Division, and Tanzania Intelligence and Security Services.

According to Caught Red-Handed workshop participants, the task team has been responsible for an increase in investigations into illegal fishing, but it is still limited by inadequate resources. Currently, there are only four navy vessels and one plane available for regular patrols of Tanzania's EEZ. 


\section{Workshop Recommendations}

The Caught Red-Handed workshop in Tanzania took place in Dar es Salaam on July 16-17, 2018, and was attended by representatives from the Deep Sea Fishing Authority, Tanzania's navy, the Tanzania Marine Police, the Multi-Agency Task Team, Tanzania Shipping Agencies Corporation, the United Nations Development Programme, the European Union, the Maritime Rescue Coordination Centre (also known as TASAC-MRCC), and the United States Embassy.

Much of the discussion focused on the best ways to leverage maritime resources in order to increase the collection and processing of illegal fishing-related information.

Delegates recommended that Tanzania:

1. GENERATE RESOURCES needed to combat illegal fishing, including:

a. increasing the government's use of technology to detect illegal fishing; and

b. increasing the quantity of vessels capable of going farther in the EEZ.

2. INCREASE PORT CONTROL by strengthening security at ports.

3. PREPARE SOPS AND A MEMORANDUM OF UNDERSTANDING TO SHARE INFORMATION with regional fusion centers.

4. USE THE VESSEL SIGHTING CHECKLIST to collect vessel information, with the Deep Sea Fishing Authority responsible for information collection and able to call on other relevant agencies, including the navy, police, Port Authority, Fisheries Division, Deep Sea Fishing Authority, TASAC, and national security agencies.

5. TRAIN THESE AGENCIES and others involved, including local fishers, in information collection.

6. CREATE A JOINT SYSTEM FOR SHARING INFORMATION and share transparently within Tanzania and regionally through the Regional Maritime Information Fusion Center in Madagascar.

7. Work with government to IMPROVE AND STRENGTHEN POLICIES, LAWS, AND ENFORCEMENT RELATED TO ILLEGAL FISHING, including requiring all vessels to have International Maritime Organization (IMO) numbers.

8. DEVELOP THE FISHING INDUSTRY in Tanzania, starting with Tanzanian fishing vessels, and build infrastructure to support it. 


\section{MAURITIUS}

\section{Overview of Fisheries Sector}

Mauritius has an EEZ of 1.9 million $\mathrm{km}^{2}$ extending from the coasts of the islands of Mauritius, Rodrigues, St. Brandon, Agalega, Tromelin, and the Chagos Archipelago. Fisheries resources exploited include an inshore artisanal fishery, an offshore demersal fishery near the Mascarene Plateau and the Chagos Archipelago, and an offshore tuna fishery. ${ }^{74}$

Fisheries are an important economic sector in Mauritius, accounting for about 1.6 percent of the GDP and employing some 12,000 people. $^{75}$ Moreover, fish is an important source of protein in local diets and the annual per capita consumption of fish averages between $22-25 \mathrm{~kg}$, which represents one-quarter of animal-protein intake. ${ }^{76}$

Coastal fisheries in Mauritius involve the lagoon and outer reef areas. This fishery is the main source of fresh fish supply for the local market. About 2,200 fishermen are involved in the coastal fishery in Mauritius using about 1,500 (mostly small) boats, mainly powered by outboard motors. These fishers use basket traps, hooks and lines, harpoons, large nets, and gillnets, mostly targeting emperors, parrotfish, rabbitfish, and mullets.

The tuna fishery is the major industrial fishery in Mauritius and the export of tuna constitutes 90 percent of the total export value of fish and fish products. ${ }^{77}$ The Mauritian fleet is composed of both surface longliners and purse seiners. In 2017 there were two purse seiners flagged by Mauritius allowed to operate both within and beyond the EEZ. ${ }^{78}$ Mauritius also has a longline fleet consisting of 11 boats of less than 24 meters, six of which are licensed to operate only within the EEZ, while five are licensed to operate both within and beyond the EEZ.

Licenses are also issued to foreign longliners that operate within Mauritius' EEZ. Most of these vessels land their catch in Port Louis, where it is then processed for export. In 2017, a total of 141 licenses were issued to longliners from the EU, Taiwan Province of China, South Korea, Japan, Indonesia, Belize, and Malaysia.

A new fisheries agreement between the EU and Mauritius was created in 2017, covering the period 8 December 2017 to 7 December $2021 .{ }^{79}$ It allows vessels from Spain, France, Portugal, and Italy to fish in Mauritian waters and is part of the Tuna Network Fisheries Agreement in the Indian Ocean.

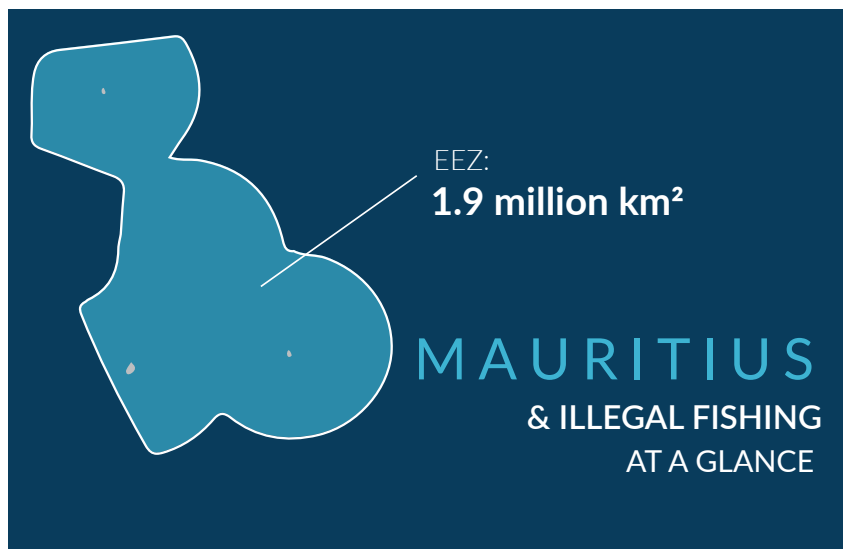

FISHERIES SECTOR:

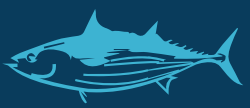

tuna accounts

for

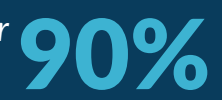

EXPORT VALUE

of fish $\&$ fish products

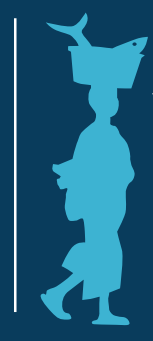

accounts for

$1.6 \%$

12,000

people employed

fish account for

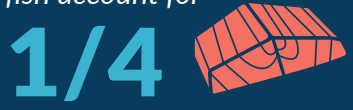

animal protein consumed

coastal fishing fleet

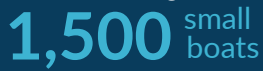

\section{CHALLENGES:}

LITTLE INFO AVAILABLE

ON THE EXTENT OF

ILLEGAL FISHING

SURVEILLANCE

over large EEZ

\section{MARITIME AGENCIES COMBATING ILLEGAL FISHING:}

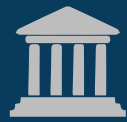

Ministry of Fisheries

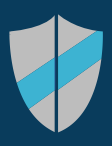

Port State

Control Unit

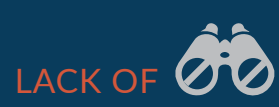




\section{Scope of Illegal Fishing}

There is little information on the extent of illegal fishing in Mauritius, but according to Subhas Chandra Bauljeewon, Divisional Scientific Officer for the Ministry of Ocean Economy, Marine Resources, Fisheries and Shipping, IUU fishing in the EEZ of Mauritius is negligible. ${ }^{80}$ Still, Caught Red-Handed workshop participants cited the large Mauritius EEZ and lack of surveillance as significant challenges to combating illegal fishing.

\section{Maritime Human Resources and Interagency Coordination}

Mauritius has set up a Fisheries Monitoring Centre situated at the Albion Fisheries Research Centre within the Ministry of Fisheries ${ }^{81}$ Specific regulations have been developed to provide the legal framework for the use of VMS in prosecutions. All local fishing boats and vessels, including carrier vessels and foreign-licensed fishing vessels, must abide by the VMS regulations, under which they have to transmit VMS information every two hours to the Fisheries Monitoring Centre. ${ }^{82}$

A special unit known as the Port State Control Unit has also been set up. ${ }^{83}$ The unit is staffed with fisheries inspectors trained to monitor all fishing vessels calling into port and to carry out boardings and inspections ${ }^{84}$ In 2017 this unit inspected 667 foreign longliners and 18 purse seiners in port.

\section{Workshop Recommendations}

The Caught Red-Handed workshop in Mauritius took place between September 10-11 in 2018 and was attended by representatives from the Mauritius police force's Anti-Drug and Smuggling Unit; the Mauritius Coast Guard; the Mauritius Revenue Authority's Customs Office; the Mauritius Immigration Office; the Mauritius Ministry of Ocean Economy, Marine Resources, Fisheries and Shipping; and the Mauritius Port Authority.

Much of the discussion focused on the best ways to increase maritime resources and inspections of suspected illegal fishing vessels.

Delegates recommended:

1. an INCREASE IN FISHING VESSEL COMPLIANCE EFFORTS and maritime observation through an increase in the number of onboard compliance officers (observers);

2. the CREATION OF AN INTERAGENCY TASK FORCE that is empowered to take a leadership role in decision-making;

3. the CREATION OF A LIST THAT IDENTIFIES LICENSED FISHING VESSELS operating in the Mauritius Exclusive Economic Zone; and

4. the CREATION OF FISHING VESSEL REPORTS combining VMS and sightings information. 


\section{MADAGASCAR}

\section{Overview of Fisheries Sector}

Madagascar is separated from Africa by the Mozambique Channel, and has a land area of approximately $587,000 \mathrm{~km}^{2}$, a coastline estimated to be $5,600 \mathrm{~km}$ long, and an EEZ of 1.2 million $\mathrm{km}^{2} .^{85}$ It is the fourth-largest island in the world and an African biodiversity hotspot, with around 80 percent of its terrestrial species being indigenous. ${ }^{86}$ Madagascar is also one of the world's poorest countries with a per capita annual income of just $\$ 419 .{ }^{87}$ Thus, subsistence fisheries are of vital importance for Madagascar's coastal communities, especially in the arid south and west of the country where agricultural productivity is low. ${ }^{88}$

Marine fishery resources are exploited by artisanal vessels (mostly canoes and dhows) and industrial vessels (mostly longliners and purse seiners) used by the foreign distant-water fishing fleet. Demersal fish, with more than 50 commercial species, form the basis of traditional fisheries in Madagascar, while farther offshore the distant-water fishing fleet targets yellowfin, skipjack, and bigeye tuna, large pelagic sharks, and tuna-like species such as marlin and swordfish.

The estimate of the added value of the marine fishery sector in 2010 was $\$ 164.8$ million, which corresponds to approximately 2 percent of the GDP. ${ }^{89}$ Current national fishery production is estimated to be around 130,000 metric tons per year, including catches by the distant-water fishing fleet. Inland fisheries and aquaculture contribute about 30,000 metric tons and 10,000 metric tons per year, respectively. ${ }^{90}$

Fish consumption per capita is $6.9 \mathrm{~kg}$ per year, below the African average of $9.4 \mathrm{~kg}$. At the same time, however, fisheries products are said to be the main source of animal protein, with an average consumption rate of 1.3 days per week.

\section{Scope of Illegal Fishing}

Despite considerable efforts to strengthen monitoring, control, and surveillance in Madagascar's waters in recent years, Caught Red-Handed delegates said that the level of illegal fishing is still believed to be high. This refers in particular to the existence of illegal fishing vessels operating in both territorial waters and offshore areas, and the transshipment of illegal catch at sea.

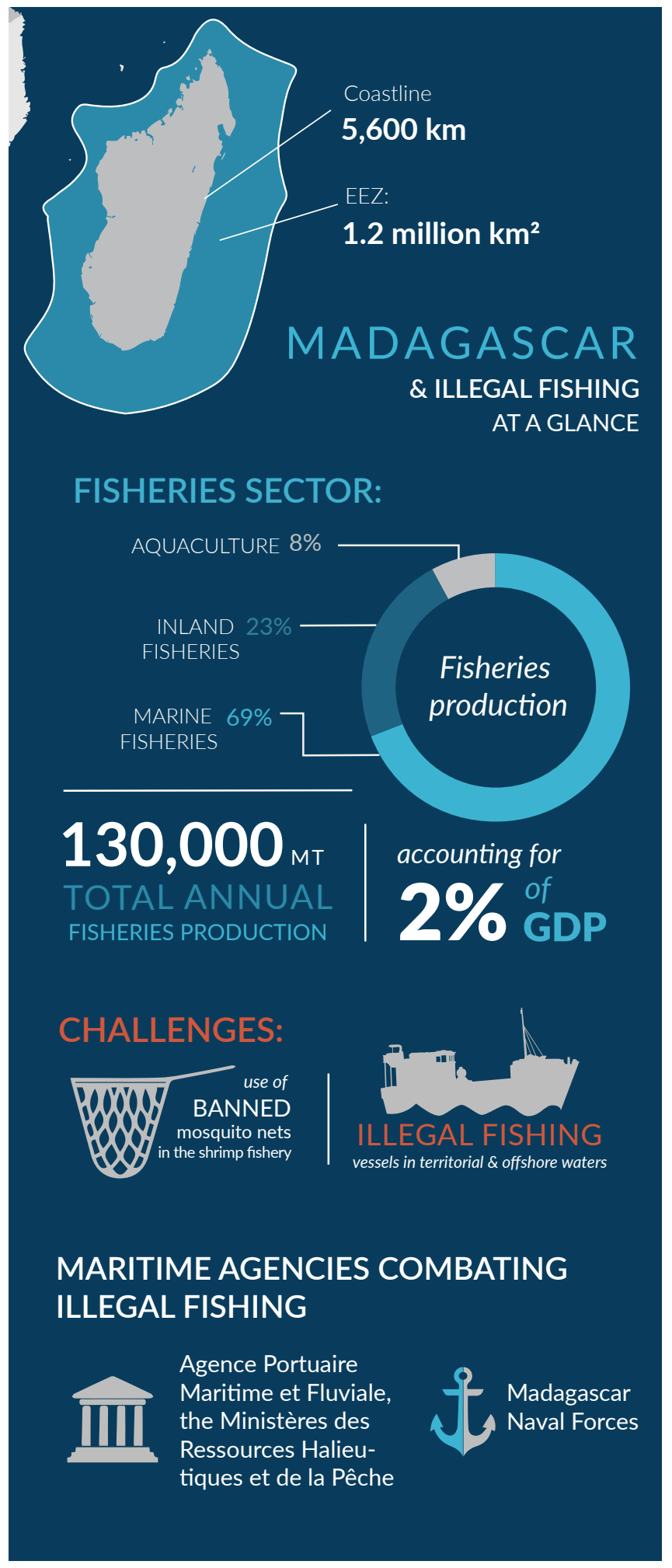


In the traditional fishery sub-sector, the incidence of IUU fishing is high in the shrimp fisheries because of the use of banned mosquito nets. ${ }^{91}$ Additionally, there have been cases of illegal Chinese, Thai, and South Korean vessels catching high-value fish such as prawns, mackerel, tuna, and shark, which are then sold for a significant profit in the markets of Beijing, Seoul, and Kuala Lumpur. ${ }^{92}$

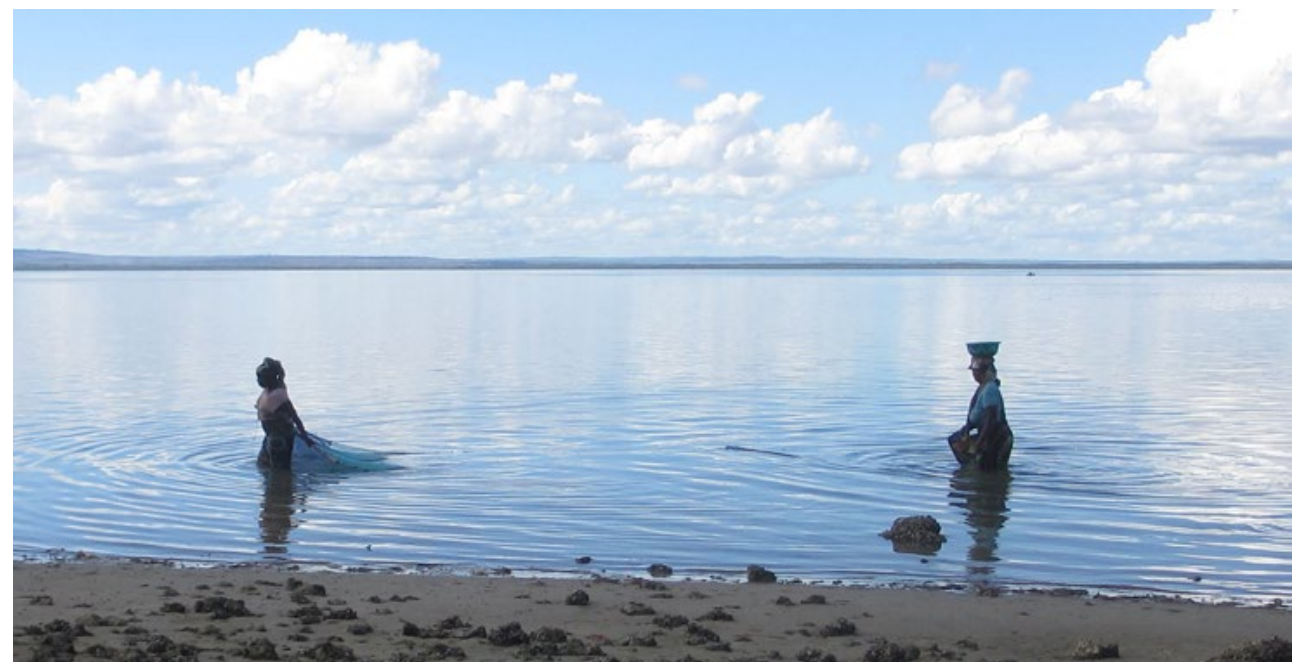

Women fishing with mosquito nets, which are banned in Madagascar. Photo: Ton Rulkens

\section{Maritime Human Resources and Interagency Coordination}

On a national level, Madagascar's fight against illegal fishing is coordinated jointly by the Agence Portuaire Maritime et Fluviale, the Ministères des Ressources Halieutiques et de la Pêche, and the Madagascar naval forces, with information supplied by the Madagascar National Fisheries Monitoring Centre.

Madagascar also hosts the Regional Maritime Information Fusion Centre (RMIFC). The RMIFC receives, processes, fuses, stores, shares, and exchanges information for the Western Indian Ocean, with the objective of issuing an alert in the event of imminent or proven danger to maritime security and safety, including:

1. illegal fishing,

2. violent acts at sea,

3. maritime incidents,

4. traffic and contraband by sea,

5. a maritime natural event,

6. irregular migration and human trafficking by sea,

7. proliferation of Arms and Security Initiative-relevant activity,

8. maritime critical infrastructure,

9. maritime tourism/recreation, and

10. marine environment-related issues.

This information is then conveyed through daily briefings, port traffic updates, press summaries, monthly maritime safety and security reports, and annual reports. Information generated by the RMIFC is used by the Regional Maritime Coordination Centre based in the Seychelles, which coordinates enforcement actions. 


\section{Workshop Recommendations}

The Caught Red-Handed workshop in Madagascar took place on September 13-14, 2018, in Antananarivo and was attended by representatives from the Agence Portuaire Maritime et Fluviale, Ministry of Transportation, National Gendarmerie, Madagascar naval forces, Madagascar National Fisheries Monitoring Centre, Ministères des Ressources Halieutiques et de la Pêche, Regional Maritime Information Fusion Centre, Ministry of Customs, and the Ministry of Justice. The workshop discussed evidence collection relating to fisheries crime and was attended by 22 participants.

Much of the discussion focused on the best ways to increase the sustainability of maritime resources through enforcement actions against illegal fishing vessels.

Delegates recommended:

1. INCREASING RESOURCES FOR KEY AGENCY FOCAL POINTS in the collection of intelligence on illegal fishing;

2. IMPROVING THE COLLECTION OF LOCATION-BASED DATA to target illegal fishing hotspots, especially in the south;

3. INCREASED TRAINING OF OFFICERS in the use of Madagascar's fishing vessel information checklist; and

4. INCREASED INTERAGENCY COORDINATION in collecting fishing vessel intelligence. 


\section{COMOROS}

\section{Overview of Fisheries Sector}

The Comoros archipelago is located in the Indian Ocean north of the Mozambique Channel, $350 \mathrm{~km}$ northwest of Madagascar and $250 \mathrm{~km}$ from the coast of Mozambique. ${ }^{93}$ The archipelago is made up of four volcanic islands totaling $1,861 \mathrm{~km}^{2}$ with $427 \mathrm{~km}$ of coastline. ${ }^{94}$ Except for the Moheli and some smaller islands, which have a more extensive continental shelf, the islands are characterized by very deep water close to shore.

Although Comoros has an EEZ of $163,752 \mathrm{~km}^{2}$, the fisheries are primarily artisanal or subsistence in nature ${ }^{95}$ and they contribute significantly to the food of the Comorian population, with an estimated per capita consumption of $25.2 \mathrm{~kg}$ in 2011.

Fishing also provides 55 percent of total employment in the agricultural sector, with about 7,000 fishers participating. ${ }^{96}$ Artisanal fisheries are conducted with small, open fiberglass boats with engines and with traditional canoes made of wood with outriggers and without engines. The main fishing gear used is hooks and lines to catch demersal fish.

Industrial longliners from Japan have fished in Comorian waters since at least the late 1950s. Although there were no formal agreements at that time, Japan has contributed funds and equipment (e.g., fiberglass vessels, fishing nets) to develop Comoros' fisheries over the years. ${ }^{97}$ Formal agreements with the European Union have been signed in recent years, which allowed up to 45 tuna seiners and 25 longliners from France, Spain, Italy, and Portugal to fish for tuna in the Comoros EEZ. ${ }^{98}$ This has recently been cancelled due to the EU red-carding Comoros in 2017 (see below).

\section{Scope of Illegal Fishing}

In 2017 the EU red-carded Comoros, identifying it as "non-cooperating third country," or flag-of-convenience state, under the EU's regulations to fight and deter illegal fishing. ${ }^{99}$ Most of the Comorian-flagged distant-water fishing fleet has no connection to the country and operates in breach of national law, mainly in the waters of West Africa. According to the EU, Comorian-flagged vessels have been found to disregard the laws applicable in the national waters they operate in and transship fish from one vessel to another, a practice related to the laundering of illegal catches. Despite receiving a yellow card in October 2015, and

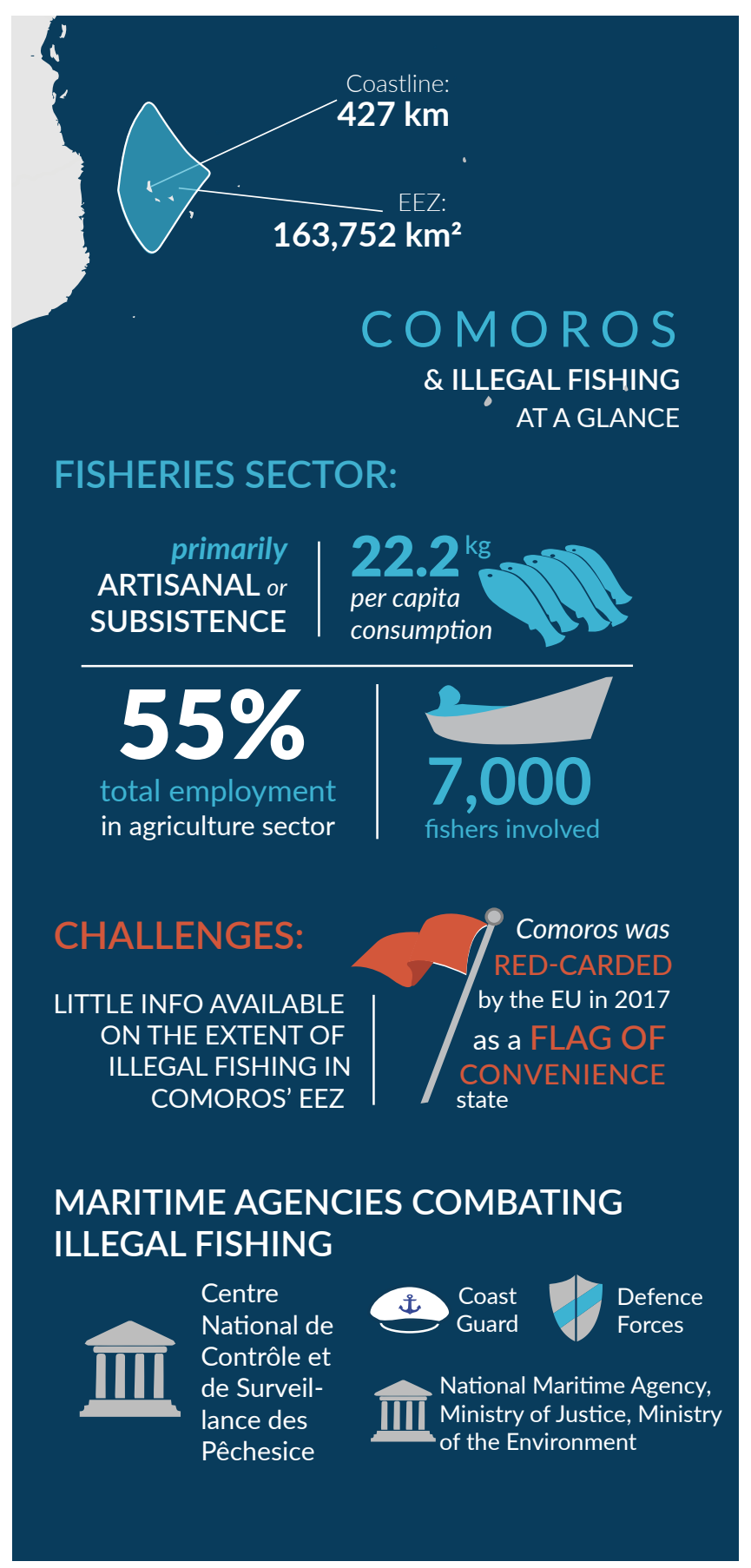


despite considerable effort by the European Commission to support Comoros in addressing the issue, according to the EU no progress has been made. ${ }^{100}$

In regard to illegal fishing occurring in the EEZ of Comoros, Caught Red-Handed delegates said little information is available.

\section{Maritime Human Resources and Interagency Coordination}

The response to cases of illegal fishing is handled by the Centre National de Contrôle et de Surveillance des Pêches, though there is very little capacity in Comoros to investigate and prosecute illegal fishing. Other Comorian agencies that play a role in investigations of illegal fishing include the Comorian coast guard, National Maritime Agency, Ministry of Justice, Ministry of the Environment, and the Comorian Defense Forces.

\section{Workshop Recommendations}

The Caught Red-Handed workshop in Comoros took place on September 17-18 in Moroni and was attended by representatives from the Comorian coast guard, National Maritime Agency, Ministry of Justice, Ministry of the Environment, Centre National de Contrôle et de Surveillance des Pêches, Comorian Defense Forces, Ministry of Transportation, and the United States Navy. The workshop discussed evidence collection relating to fisheries crime and was attended by 21 participants.

Much of the discussion focused on the best ways to increase maritime resources and inspections of suspected illegal fishing vessels.

Delegates recommended:

1. USING SEAVISION AS AN AID in maritime domain awareness;

2. INCREASING CAPACITY-BUILDING EFFORTS to train personnel in the use of SeaVision and other monitoring technologies;

3. INCREASED INTERAGENCY COORDINATION IN COLLECTING FISHING VESSEL INTELLIGENCE, utilizing the sightings checklist; and

4. INCREASED INTERAGENCY COORDINATION IN VESSEL LICENSING, especially in regard to foreign vessels. 


\section{SEYCHELLES}

\section{Overview of Fisheries Sector}

The Republic of Seychelles is an archipelago consisting of 115 islands and spread across an EEZ of about 1.3 million $\mathrm{km}^{2} .{ }^{101}$ The Seychelles has a coastline length of about 491 $\mathrm{km}$ and an economy largely based on the tourism and fishery sectors and the related services. ${ }^{102}$

The expansion of the fisheries sector in the Seychelles began in the mid-1980s with the construction of Port Victoria and culminated a decade later with the opening of the tuna canning factory. Today, the Indian Ocean Tuna factory in the Seychelles is the nation's largest employer, processing an average of $\mathbf{3 5 0}$ tons of tuna a day, while the fishery sector is the most important export sector, accounting for an estimated 90 percent of total export revenues. ${ }^{103}$

The fishery sector also accounts for about 8 percent of the GDP and an estimated 11 percent of the country's formal employment. Moreover, fish consumption is $64 \mathrm{~kg} / \mathrm{year}$, which is the highest in Africa and one of the highest in the world. ${ }^{104}$

The Seychelles' fishery sector has three main components: artisanal fisheries, carried out by local fishers with small motorized boats targeting mainly demersal and semipelagic species; a semi-industrial fishery, consisting of locally owned long-liners targeting tuna and swordfish; and industrial fisheries, comprising foreign-owned purse seiners and large longliners. ${ }^{105}$

Industrial fishing in the Seychelles' EEZ is conducted by both Seychelles-flagged tuna vessels and foreign tuna fleets, including European purse seiners and Taiwanese longliners. ${ }^{106}$ In 2015, French and Spanish purse seiners dominated the total catch inside the Seychelles EEZ, while the longline fleet had 45 vessels flagged to Seychelles, 85 to Taiwan Province of China, 19 to China, and the rest split among Japan (2), Korea (2), Thailand (2), Indonesia (1), the Philippines (1), and Tanzania (1). ${ }^{107}$

\section{Scope of Illegal Fishing}

Caught Red-Handed delegates mentioned a high level of illegal fishing occurring in the Seychelles EEZ despite increased patrols in recent years. But delegates also said that fishing regulations are well-enforced and compliance

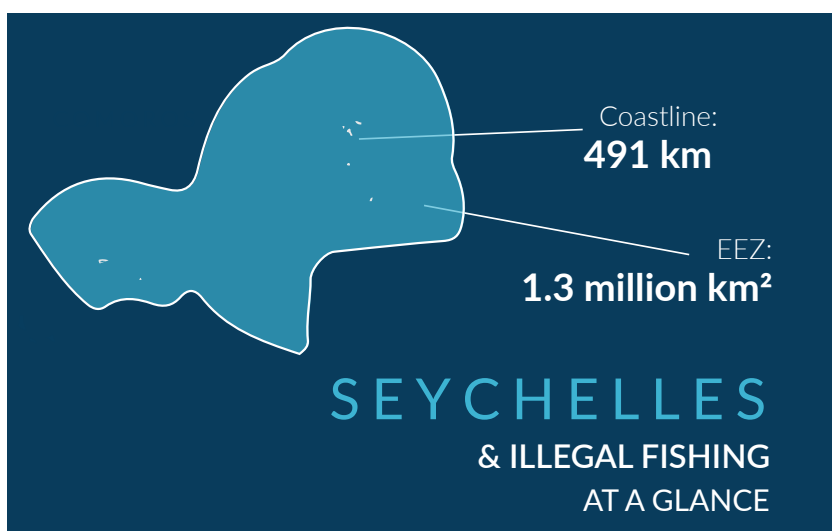

FISHERIES SECTOR:
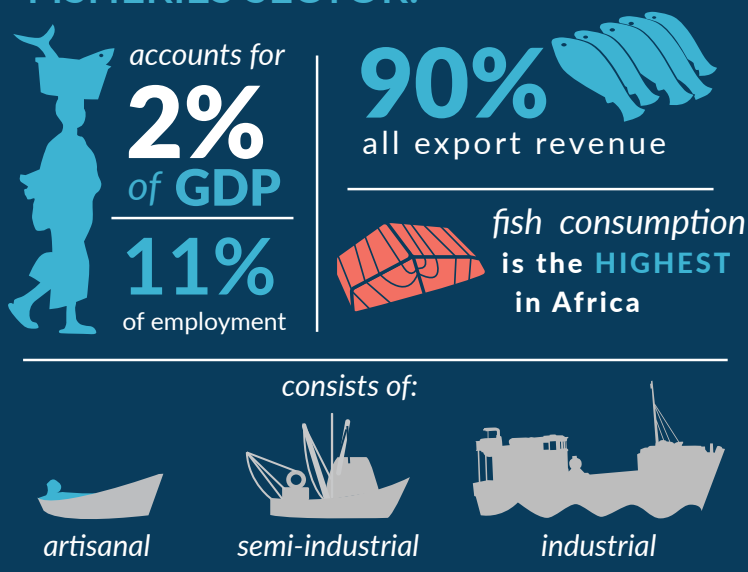

CHALLENGES:

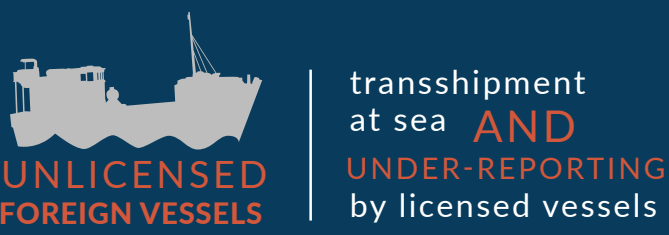

\section{MARITIME AGENCIES COMBATING ILLEGAL FISHING}
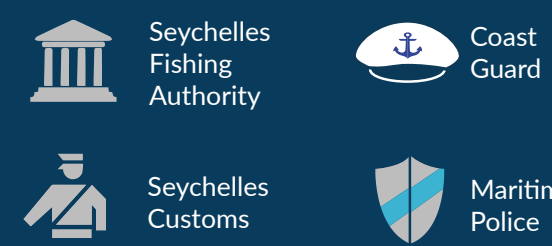

Customs

Maritime Police 
is good with regard to the industrial tuna fisheries. However, there is illegal fishing by foreign unlicensed vessels, including transshipment at sea, under-reporting by licensed fishing vessels, and non-compliance by Seychelles-flagged foreign vessels. ${ }^{108}$

In November 2018 the captain of a Sri Lankan-flagged vessel was arrested for allegedly fishing illegally in the waters of Seychelles, while a second captain is being investigated after two boats were intercepted by the Seychelles Coast Guard and evidence observed. ${ }^{109}$ The Sri Lankan-flagged vessels were first spotted by local fishermen around 90 nautical miles southeast of Mahé, the main island.

In June of 2018 six Sri Lankan nationals were held by local

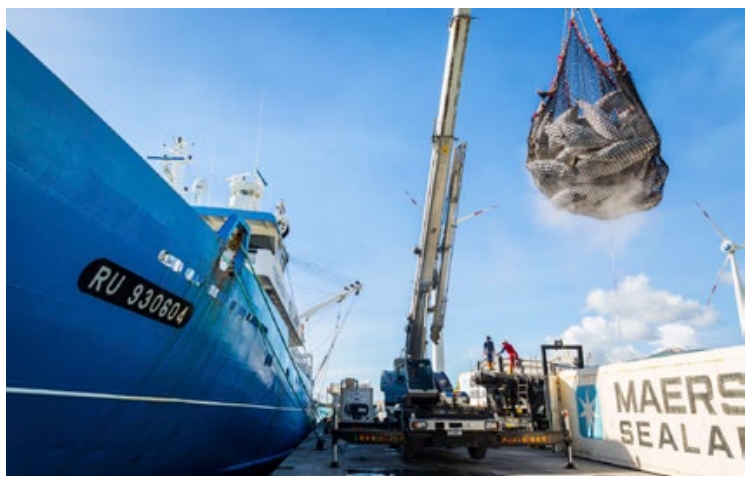

Yellowfin tuna is unloaded from an industrial fishing vessel at port in Seychelles. Photo: Jason Houston, the Nature Conservancy. law enforcement after their fishing boat was intercepted on suspicion of fishing illegally in the waters of Seychelles. ${ }^{110}$ The Sri Lankan-flagged vessel was spotted by Seychelles Coast Guard patrol ship Andromache northwest of the main island of Mahé during a routine patrol. A coast guard team was subsequently sent on board the suspicious vessel to conduct an inspection, during which evidence relating to illegal fishing was observed.

\section{Maritime Human Resources and Interagency Coordination}

The Seychelles Fishing Authority, Seychelles Coast Guard, Seychelles Customs, and Seychelles Maritime Police are all involved at varying levels in stopping illegal fishing in the country.

The Seychelles Fisheries Monitoring Centre conducts compliance monitoring of all fishing vessels' reporting requirements, VMS, and validation of statistical documents for the International Commission for the Conservation of Atlantic Tunas, the IOTC, and EU and non-EU catch certificates. ${ }^{111}$ The Seychelles Enforcement Unit carries out all inspections with regards to port state inspection, land inspection, and sea and air surveillance duties pertaining to national and regional requirements.

Moreover, the Seychelles is host to the Regional Coordination Operations Centre ${ }^{112}$ (RCOC) for the Western Indian Ocean. The RCOC works with member states to pool resources in a cost-efficient manner to respond to maritime crimes. The center uses IORIS, a new secure information-sharing and incident-management tool developed under a European Unionfunded program called CRIMARIO. IORIS enables countries in the region to coordinate operations when maritime security threats are identified, including incidents of illegal fishing.

\section{Workshop Recommendations}

The Caught Red-Handed workshop in Seychelles took place on November 14, 2018, in Victoria and was attended by representatives from the Seychelles Fishing Authority, Seychelles Coast Guard, Seychelles Customs, and Seychelles Maritime Police.

Much of the discussion focused on the best ways to increase maritime resources and inspections of suspected illegal fishing vessels. The meeting resulted in a recommendation for increased sharing of interagency information on vessels suspected of fishing illegally. 


\section{SOMALIA}

\section{Overview of Fisheries Sector}

Somalia is situated in the Horn of Africa at the junction of the Gulf of Aden and the Indian Ocean, and is bordered by Djibouti, Ethiopia, and Kenya. It has a surface area of about $637,700 \mathrm{~km}^{2}$ and a coastline of approximately 3,300 $\mathrm{km}$, which is the longest in continental Africa. Somalia also claims an EEZ of some $830,389 \mathrm{~km}^{2} .{ }^{113}$

Somalia has undergone a prolonged period of conflict and insecurity over the last 30 years, with intense fighting, population displacement, and food insecurity creating a humanitarian crisis. Despite this, the country has maintained a relatively healthy informal economy ${ }^{114,} 115$, 116 largely based on livestock, telecommunications, and remittance and money transfers.

Agriculture is the most important sector in the Somali economy with livestock accounting for about 40 percent of GDP and more than 50 percent of export earnings. Nomads and semi-pastoralists, who are dependent upon livestock for their livelihood, make up a large portion of the population. The agriculture sector (including both livestock and fisheries) accounts for about 65 percent of the GDP.

The fishery sector is considered a marginal sector in terms of aggregated economic output, but it is gaining importance. Though fisheries only contribute between 1 and 2 percent to the national GDP, they are critical to coastal communities, providing employment, income, and food. In 2005, it was estimated that there were about 30,000 full-time and 60,000 part-time jobs directly involved in fishing.

According to FAO estimates, per capita fish consumption was $3.1 \mathrm{~kg}$ for 2009, which places the country on the lower end of fish consumers among African countries (where the average is $9.4 \mathrm{~kg}$ ). However, much of this fish protein is consumed in coastal villages, making fish vital to food security in those locations.

Somalia also has a developing offshore fisheries sector dominated by foreign vessels. In 2018 Somalia granted fishing licenses to 31 Chinese vessels to exploit tuna and tuna-like species off its coast in a bid to tap the sector for economic growth. The vessels are associated with the China Overseas Fisheries Association created in 2012. Ships will be allowed to operate for a one-year period in

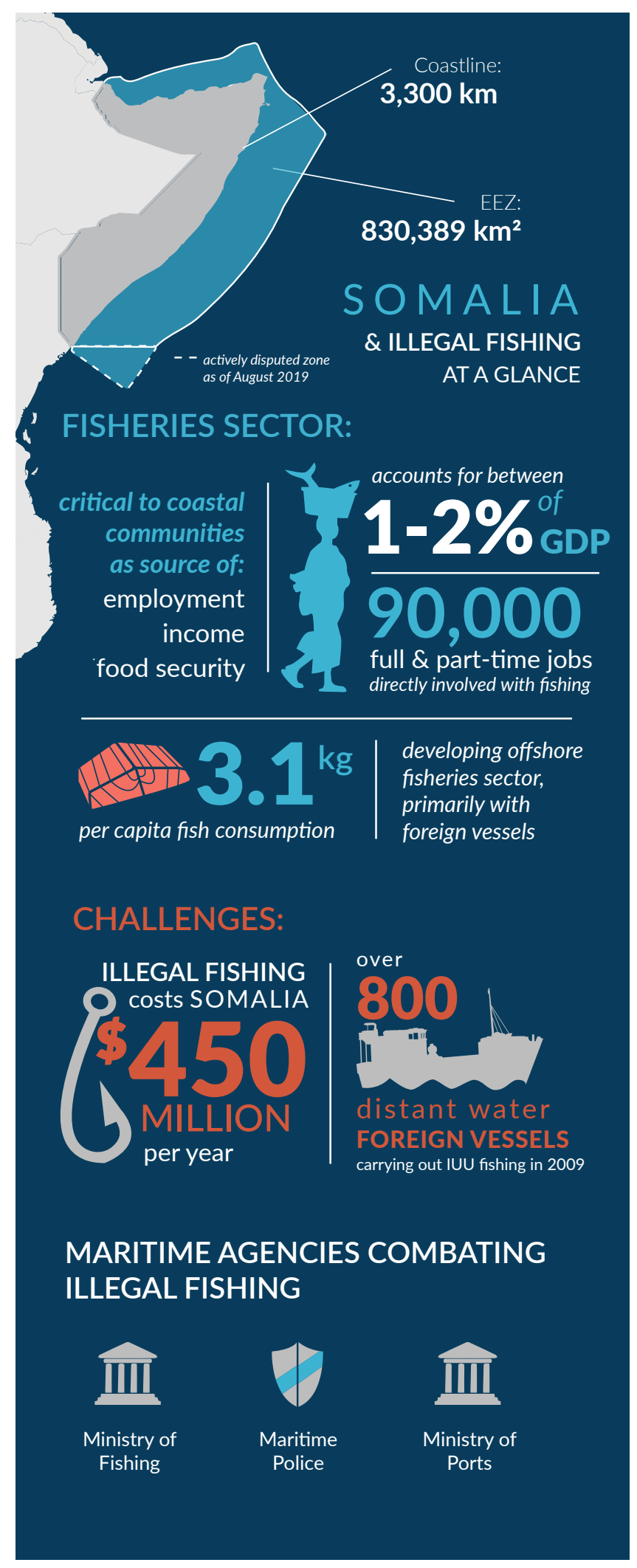




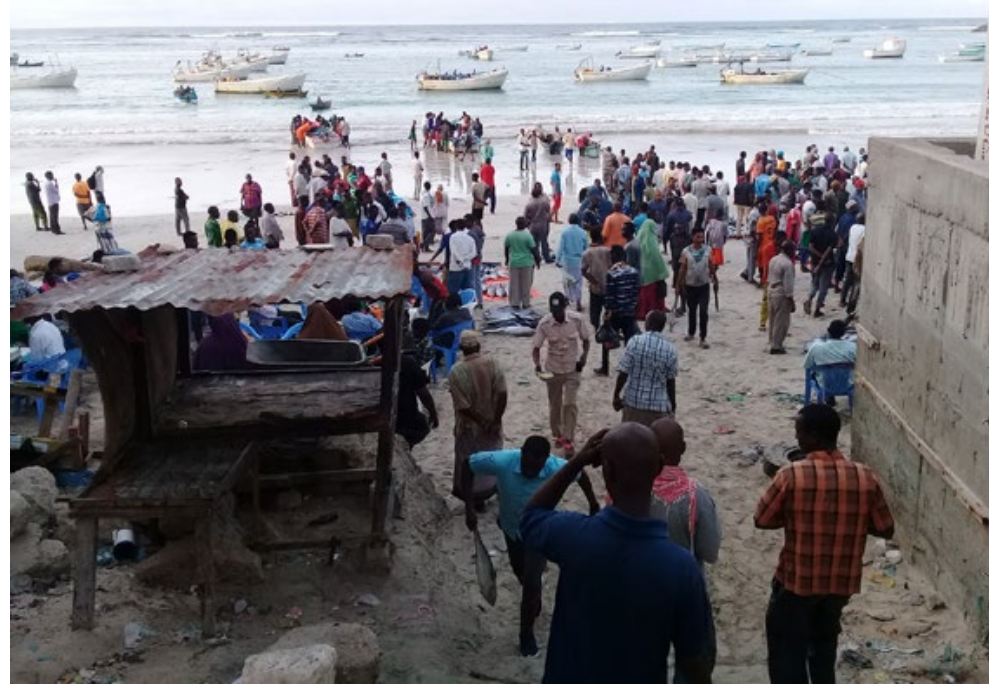

Lido beach, Mogadishu, where fishers land and sell their catch. Fisheries are vitally important to coastal communities in Somalia. Photo: Jamal Hassan.
Somali waters, with the agreement stipulating an automatic renewal for an additional year. Licensed foreign vessels will not be permitted to operate within 24 nautical miles of shore in order to protect small-scale fishing operations. Upon entering or leaving Somalia's EEZ, the vessels will also have to declare their positions, along with weight of catch by species.

\section{Scope of Illegal Fishing}

According to the FAO's High Seas Task Force (HSTF), an estimated 700 distant-water fishing nation vessels were engaged in unlicensed fishing in Somali waters in 2005. Four years later, according to the HSTF, more than 800 distant-water fishing nation vessels from over 17 nations were carrying out IUU fishing annually in Somali waters. Distant-water fishing nation vessels appear to catch fish from Somali waters with an estimated value of more than $\$ 450$ million per year.

2017 UN Security Resolution 2383 expressed "serious concern over reports of [IUU] fishing in Somalia's EEZ," and noted "the complex relationship between IUU fishing and piracy, recognizing that IUU fishing accounts for millions of dollars in lost revenue for Somalia each year, and can contribute to destabilization among coastal communities."117

According to a report in 2018 by the IOTC, ${ }^{118}$ there has been no MCS of the marine resources or centralized data collection system on marine products for either inshore or offshore fisheries. Thus, strengthening capacity for development and implementation of a central maritime database for fisheries is a key priority.

Several trawlers have been active along the coast of Somalia and operate illegally. ${ }^{119,}{ }^{120,121}$ These vessels have been fishing on the narrow continental shelf in Somalia, in particular in Puntland (north and east coast) and all along the Indian Ocean coast of Somalia. They are targeting demersal fish including groupers and snappers along with lobsters, and unloading their catch in Salalah (Oman), Ajman (UAE), or Mombasa (Kenya). One trawler was arrested in 2018 near Socotra by the INS Sunayna, a patrol vessel of the Southern Naval Command based in Kochi. ${ }^{122}$ Upon further investigation, investigators also uncovered four AK-47s and a machine gun.

\section{Maritime Human Resources and Interagency Coordination}

On the federal level, Somalia utilizes the Ministry of Fisheries, maritime police, and the Ministry of Ports to fight illegal fishing. The Caught Red-Handed workshop in Mogadishu was considered the first meeting of a new interagency IUU Fishing Task Force, which will be charged with coordinating actions to fight fisheries-related crimes. This task force will be chaired jointly by the Minister of Fisheries and the Minister of Ports. 


\section{Workshop Recommendations}

The workshop in Somalia, co-hosted by EUCAP Somalia on November 18, 2018, was attended by Federal Minister for Fisheries H.E. Abdilahi Bidham Warsame and Federal Minister for Ports and Maritime Transportation H.E. Marian Aweys, along with senior staff from the Ministry of Fisheries, Maritime Police Unit, Ministry of Ports, and the Attorney General's Office. The workshop produced several recommendations, including:

1. CREATING AN INTERAGENCY IUU FISHING TASK FORCE and/or information-sharing mechanism jointly chaired by the Ministry of Fisheries and the Ministry of Ports and Marine Transport.

2. CREATING AN INTERAGENCY MECHANISM FOR ENFORCEMENT of IUU fishing laws.

3. STRENGTHENING PROCEDURES FOR THE COLLECTION, DISSEMINATION, AND SHARING OF FISHING VESSEL INFORMATION, and using the fishing activity sightings checklist (see Appendix I).

4. CONDUCTING INTERAGENCY STAKEHOLDER MAPPING of all national maritime agency personnel and identifying the expertise of staff members, especially those who have expertise in fisheries enforcement.

5. CREATING AN AWARENESS CAMPAIGN focused on communicating the current and future effects of IUU fishing in Somalia to all maritime agency personnel, including the potential for fisheries-related conflict.

6. IDENTIFYING INDIVIDUALS WITHIN THE JUDICIARY AND PROSECUTOR'S OFFICE WITH EXPERTISE IN MARITIME ISSUES and creating trainings around prosecuting IUU fishing cases.

7. WORKING TO PASS THE NEW MARITIME CODE.

8. WORKING WITH EUNAVFOR ON STRENGTHENING INFORMATION SHARING around sUsPected illegal fishing vessels.

9. STRENGTHENING CAPACITY-BUILDING around acquiring stronger maritime domain awareness technologies while training staff in their use. 


\section{REFERENCES}

1 Marie Lecomte, Julien Rochette, Yann Laurans, Renaud Lapey, Indian Ocean Tuna Fisheries: Between Development Opportunities and Sustainability Issues, IDDRI, 2017, https://www.iddri.org/sites/default/files/PDF/ Publications/Hors\%20catalogue\%20Iddri/201811-tunaindian\%20oceanEN.pdf.

2 Indian Ocean Tuna Commission, Status Summary for Species of Tuna and Tuna-Like Species Under the IOTC Mandate, as well as Other Species Impacted by IOTC Fisheries, 2018, https://www.iotc.org/science/status-summary-speciestuna-and-tuna-species-under-iotc-mandate-well-otherspecies-impacted-iotc.

3 "ISSF Calls for Attention to Yellowfin Overfishing in the Indian Ocean," Undercurrent News, May 10, 2018, https:// www.undercurrentnews.com/2018/05/10/issf-calls-forattention-to-yellowfin-overfishing-in-the-indian-ocean/.

4 EU, "Program to Promote Regional Maritime Security (MASE)," 2016, https://eeas.europa.eu/headquarters/ headquarters-homepage/8407/program-promoteregional-maritime-security-mase en, accessed 1 May 2019.

5 Stop Illegal Fishing, FISH-i Africa: Issues, Investigations and Impacts, 2016, https://fish-i-africa.org/wp-content/ uploads/2016/07/FISH-i Impacts report second edition 20022017 COMPLETE WEB-1.pdf.

6 Interpol, “Fisheries Crime," 2018, https://www.interpol. int/en/Crimes/Environmental-crime/Fisheries-crime.

7 Stop Illegal Fishing, International Symposium on FishCRIME, 12-13 October 2015, Cape Town, South Africa, http:// www.fishcrime.info/.

8 International Maritime Organization, Revised Code of Conduct Concerning the Repression of Piracy, Armed Robbery Against Ships, and Illicit Maritime Activity in the Western Indian Ocean and the Gulf of Aden Area 2017, http://www.imo.org/en/OurWork/Security/ PIU/Documents/A2\%20Revised\%20Code $\% 200 f \% 20$ Conduct $\% 20$ Concerning\%20The $\% 20$ Repression $\% 200 f \% 20$ Piracy\%20Armed\%20Robbery\%20Against\%20Ships\%20 Secretariat.pdf.

9 "Cutlass Express," United States Africa Command 2019, https://www.africom.mil/what-we-do/exercises/cutlassexpress, accessed 2 May 2019.

10 Paige M. Roberts, Laura C. Burroughs, and Robert $\mathrm{H}$. Mazurek, “An Exploration of Federal Fisheries Management
Agencies in Eastern Africa," Secure Fisheries, February 2017, https://doi.org/10.18289/oef.2017.014.

11 Sarah Percy, "Maritime Crime and Naval Response," Survival 58, no.3 (2016): 155-186, https://doi.org/10.1080 00396338.2016 .1186986$.

12 Federal Government of Sri Lanka, Department of Fisheries and Aquatic Resources, Sri Lanka Plan of Action to Prevent, Deter, and Eliminate IIlegal, Unreported, and Unregulated Fishing, 2015.

13 Food and Agriculture Organization of the United Nations, Country Programming Framework for Sri Lanka: 2018-2022, 2017.

14 Augustin Siluvaithasan Sosai, "Illegal Fishing Activity: A New Threat in Mannar Island Coastal Area (Sri Lanka)," Transylvanian Review of Systematical and Ecological Research, 2015.

15 Food and Agriculture Organization of the United Nations, Asia-Pacific Fishery Commission Report of the Executive Committee: Seventy-fifth Session, 2014.

16 Food and Agriculture Organization of the United Nations, Report on the Cost-Benefit Analysis of the Monitoring, Control, and Surveillance (MCS) System and Tools Developed by Sri Lanka, 2019.

17 European Union, Council Implementing Decision 2015/200, 26 January 2015.

18 European Union, "Fighting illegal Fishing: Warnings for Kiribati, Sierra Leone and Trinidad \& Tobago, while Sri Lanka is Delisted," European Commission, 21 April 2016.

19 "Sri Lanka Increases Fine on Illegal Fishing to LKR 1.75 to Prevent Foreign Vessels from Entering Lankan Waters," First Post, 14 February 2018, https://www.firstpost.com/ world/sri-lanka-increases-fine-on-illegal-fishing-to-lkr1-75-to-prevent-foreign-vessels-from-entering-lankanwaters-4322301.html.

20 Shashikala Madanayaka and Kumari Madanayaka, "Illegal Fishing Issue as a Non-traditional Security Threat to Sri Lanka (With Reference to India)," paper presented at the $8^{\text {th }}$ Annual International Research Conference, August 2015.

21 Hassan Shinan, Ministry of Fisheries and Agriculture, email to author, 3 March 2019.

22 Food and Agriculture Organization of the United Nations, "FAO Fishery Country Profile: The Republic of Maldives," http://www.fao.org/fi/fcp/en/MDV/profile.htm, accessed 19 February 2019. 
23 World Bank Group, "Maldives Overview," 21 December 2018, https://www.worldbank.org/en/country/maldives/ overview.

24 Juliette Makandi Guantai, "Environmental and Social Management Framework Maldives-Sustainable Fisheries Development Project," Ministry of Fisheries and Agriculture, World Bank Report Number SFG2883, 1 December 2016.

25 M. Hemmings, S. Harper, and D. Zeller, "Reconstruction of Total Marine Catches for the Maldives: 1950-2010," in K. Zylich, D. Zeller, M. Ang, and D. Pauly (eds.), Fisheries Catch Reconstructions: Islands, Part IV, 107-120, Fisheries Centre Research Reports 22, no. 2 (2014: Fisheries Centre, University of British Columbia).

26 Mohamed Ahusan, M Shiham Adam, Adam Ziyad, Ahmed Shifaz, Mohamed Shimal, and Riyaz Jauharee, "Maldives National Report Submitted to the Indian Ocean Tuna Commission Scientific Committee-2017," Government of the Republic of Maldives Ministry of Fisheries and Agriculture, 2017, IOTC-2018-SC21-NR16.

27 "Potential IUU Fishing Operators in Maldivian Waters Get Serious Warnings," FIS World News, 9 October 2017, https://www.fis.com/fis/worldnews/worldnews. asp? monthyear $=10-2017 \&$ day $=9 \& i d=94146 \& \mathrm{l}=e \&$ country $=0 \&$ special $=\& n d b=1 \& d f=0$.

28 Hassan Shinan, Ministry of Fisheries and Agriculture, email to author, 3 March 2019.

29 "Coast Guard Intercepts Illegal Fishing Vessel with 200 Tons of Tuna," Maldives Independent, 12 January 2018, https://maldivesindependent.com/environment/coastguard-intercepts-illegal-fishing-vessel-with-200-tons-oftuna-135141.

30 "Sri Lankan Boat was Seized with Tonne of Fish," Maldives Independent, 26 December 2018, https:// maldivesindependent.com/society/sri-lankan-boat-wasseized-with-tonne-of-fish-143268.

31 "Fishery and Aquaculture Country Profiles: The Republic of Kenya," Food and Agriculture Organization of the United Nations, http://www.fao.org/fishery/facp/KEN/en, accessed 19 February 2019.

32 Frédéric Le Manach, Caroline A. Abunge, Timothy R. McClanahan, and Daniel Pauly, "Kenya's Marine Fisheries Catch, 1950-2010," The Sea Around Us, 2015, http://www. seaaroundus.org/doc/publications/chapters/2015/LaManach-et-al-Kenya.pdf.
33 "Africa Program for Fisheries," World Bank Group, http:// www.worldbank.org/en/programs/africa-program-forfisheries, accessed 19 February 2019.

34 "Animals and Fisheries Sector Profile of Kenya," Fortune of Africa Kenya, https://fortuneofafrica.com/kenya/animalsfisheries-sector-kenya/, accessed 19 February 2019.

35 “Mission Report Kenya," WUR E-depot, 31 March 2017, http://edepot.wur.nl/413271.

36 "Kenya-National Report 2018," Indian Ocean Tuna Commission report IOTC-2018-SC21-NR12, 23 November 2018, http://www.iotc.org/fr/documents/SC/21/NR12.

37 "State of Coast Report for Kenya," National Environment Management Authority of Kenya, 2017, https://www. nema.go.ke/images/Docs/REPORTS/SOC\%202nd\%20 Edition\%20final\%20report 19\%2010\%202017.pdf.

38 Le Manach, Abunge, McClanahan, and Pauly, "Kenya's Marine Fisheries Catch, 1950-2010."

39 John W. Karungo, Kenya Fisheries Service, email to author, 28 February 2019.

40 "Sh10 Billion Lost to Illegal Fishing Yearly in Exclusive Zone-Bett," The Star, 3 August 2017, https://www.thestar.co.ke/news/2017/08/03/sh10-billion-lost-to-illegalfishing-yearly-in-exclusive-zone-bett c1609024.

41 Beverly Muthoki Musili, "Illegal, Unreported and Unregulated Fishing and Fisheries Crimes Key Threats to Security and Fishing Industry," Kenya Institute for Public Policy Research and Analysis, 3 July 2018, http://kippra. or.ke/illegal-unreported-and-unregulated-fishing-andfisheries-crimes-key-threats-to-security-and-fishingindustry/.

42 Fadhili Frederick, "Kenya Navy Arrests 109 Tanzanians for Illegal Fishing," Business Daily, 6 June 2018, https:// www.businessdailyafrica.com/news/counties/KenyaNavy-arrests-109-Tanzanians-for-illegal-fishing/40031424598582-b8mkz/index.html.

43 Elisha Otieno, "Police Arrest 16 Tanzanian Fishermen in Migori," Daily Nation, 18 November 2018, https://www. nation.co.ke/counties/migori/Tanzanian-fishermenarrested-in-Migori/1183306-4857626-format-xhtmletm2f7/index.html.

44 Alphonce Gari, "26 Tanzanians Among Group Arrested for Illegal Fishing in Malindi," The Star, 4 December 2018, https://www.the-star.co.ke/news/2018/12/04/26tanzanians-among-group-arrested-for-illegal-fishing-inmalindi c1860789. 
45 "Kenya Targets 'Fish Thieves' with New Coastguard," BBC News, 19 November 2018, https://www.bbc.com/news/ world-africa-46266978.

46 George Tubei, "Uhuru Kenyatta Kenya Launches Coast Guard Service as it Fights to Stop \$100 Million Going Down the Drain in Illegal Fishing and Drug Trafficking Annually," Business Insider by Pulse Kenya, 19 November 2018, https:// www.pulselive.co.ke/bi/uhuru-kenyatta-kenya-launchescoast-guard-service-as-it-fights-to-stop-dollar100/b8bjf37.

47 Food and Agriculture Organization of the United Nations, "FAOSTAT," http://www.fao.org/faostat/en/, accessed 21 February 2019.

48 Food and Agriculture Organization of the United Nations, "Country Profiles: Mozambique," http://www.fao.org/ countryprofiles/index/en/?iso3=MOZ, accessed 21 February 2019.

49 "Mozambique: Fisheries Minister Knows Nothing About Chinese Boats," AllAfrica.com, 7 December 2018, https:// allafrica.com/stories/201812100023.html.

50 Julian Pepperell, Shane Griffiths, and Nelly Kadagi, "Acquisition of Catch-and-Effort and Size Data from Sport Fisheries in the Western Indian Ocean," Indian Ocean Tuna Commission report IOTC-2017-SC20-INF04, October 2017, http://www.iotc.org/sites/default/files/ documents/2017/11/IOTC-2017-SC20-INF04.pdf.

51 European Commission, "Mozambique Fisheries Partnership Agreement," https://ec.europa.eu/fisheries/cfp/internatio nal/agreements/mozambique en, accessed 20 February $\underline{2019}$.

52 Mark Godfrey, "China: Yu Yi Celebrates its First Foray into Mozambique," Club of Mozambique, 29 November 2018, https://clubofmozambique.com/news/china-yu-yicelebrates-its-first-foray-into-mozambiquel.

53 Food and Agriculture Organization of the United Nations, "General Geographic and Economic Data: Fisheries data," FID/CP/MOZ, September 2007, http://www.fao.org/ fishery/docs/DOCUMENT/fcp/en/FI CP MZ.pdf.

54 UNCTAD, "Case Study: Mozambique," in Fishery Exports and the Economic Development of LDCs, UNCTAD/ALDC/2017/2, 2017, https://unctad.org/en/PublicationChapters/aldc2017 d2 ch07 en.pdf.

55 Food and Agriculture Organization of the United Nations, "Mozambique Fishery Overview," World Fisheries Trust, http://worldfish.org/GCl/gci assets moz/ Mozambique\%20Fishery\%200verview\%20-\%20FAO.pdf.
56 Leonid Chimarizene, presentation at Caught Red-Handed Workshop, 12 July 2018.

57 "Mozambique: Illegal Fishing Costs Mozambique 60 Million Dollars a Year," AllAfrica.com, 26 June 2018, https://allafrica. com/stories/201806270166.html.

58 “ANTILLAS REEFER-IMO 8603688," ShipSpotting.com, 14 July 2008, http://www.shipspotting.com/gallery/photo. php?lid=683138, accessed 11 March 2019.

59 "Mozambique Confiscates Foreign Fishing Vessel Nessa 7," FISH-i Africa, 18 March 2016, https://fish-i-africa.org/ mozambique-confiscates-foreign-fishing-vessel-nessa-7/.

60 "SeychellesBoatFishinglllegallySeized," ClubofMozambique, 26 December 2018, https://clubofmozambique.com/news/ seychelles-boat-fishing-illegally-seized/.

61 "República De Moçambiqueministerio Do Mar, Águas Interiores E Pescasdirecção Nacional De Operações," Presentation at Caught Red-Handed Workshop, 12 July 2018.

62 Leonid Chimarizene, Ministry of Sea, Inland Waters and Fisheries, email to author, 27 February 2019.

63 "Southern African Development Community Promotes Regional MCS Approach," Stop Illegal Fishing, 1 November 2018, $\quad$ https://stopillegalfishing.com/news-articles/ southern-african-development-community-promotesregional-mcs-approach/.

64 ASCLME, GEF, and the United Nations Development Programme, "Tanzania: National Marine Ecosystem Diagnostic Analysis," 2012, https://wedocs.unep.org/ bitstream/handle/20.500.11822/25887/Tanzania MEDA. pdf?sequence $=1$.

65 Elise Bultel, Beau Doherty, Adam Herman, Frédéric Le Manach, and Dirk Zeller, "An Update of the Reconstructed Marine Fisheries Catches of Tanzania with Taxonomic Breakdown," The Sea Around Us, 2 March 2015, https:// www.researchgate.net/publication/272996844 An update of the reconstructed marine fisheries catches of Tanzania with taxonomic breakdown.

66 "FAO Country Profiles: Tanzania," Food and Agriculture Organization of the United Nations, http://www.fao.org/ countryprofiles/index/en/?iso3=TZA, accessed 21 February 2019.

67 Upendo Mwaisunga Hamidu, "Assessment of the Marine Artisanal Fisheries in Tanzania Mainland," Ministry of Livestock and Fisheries Development Department of 
Fisheries Resource Development, United Nations University Fisheries Training Program Final Project 2012, http://www. unuftp.is/static/fellows/document/upendo12prf.pdf.

68 "The Tanzanian Fisheries Sector: Challenges and Opportunities," United Republic of Tanzania Ministry of Agriculture, Livestock and Fisheries, September 2016, http://tanzania.um.dk/ /media/Tanzania/Documents $\angle$ Business $\% 20$ Sector / The $\% 20$ Tanzanian $\% 20$ Fisheries\%20Sector\%20\%20Challenges\%20and\%20 opportunities.pdf?la=en.

69 "The Value of African Fisheries," FAO Fisheries and Aquaculture Circular 1093, FIPS/C1093, 2014, http://www. fao.org/3/a-i3917e.pdf.

70 Indian Ocean Tuna Commission, "Tanzania- National Report (2016)," IOTC-2016-SC19-NR29, 16 November 2016, http://www.iotc.org/documents/tanzania\%E2\%80\%93national-report-2016.

71 Hamidu, "Assessment of the Marine Artisanal Fisheries in Tanzania Mainland."

72 "Tanzanian Authorities Crack Down on Illegal Fishing Operations," Stop Illegal Fishing, 5 February 2018, https://stopillegalfishing.com/news-articles/tanzanianauthorities-crack-illegal-fishing-operations/.

73 Romy Chevalier, "Safeguarding Tanzania's Coral Reefs: The Case of Illegal Blast Fishing," South African Institute of International Affairs, 31 May 2017, https://saiia.org.za/ research/safeguarding-tanzania-s-coral-reefs-the-case-ofillegal-blast-fishing/.

74 "FAO Fishery Country Profile: The Republic Of Mauritius," Food and Agriculture Organization of the United Nations, http://www.fao.org/fishery/docs/DOCUMENT/fcp/en/ FI CP MU.pdf, accessed 25 February 2019.

75 "Fisheries: Policy Documents," Republic of Mauritius Ministry of Ocean Economy, http://oceaneconomy.govmu. org/English/Pages/Fisheries---Policy-Documents.aspx, accessed 25 February 2019.

76 "National Plan of Action to Prevent, Deter and Eliminate Illegal, Unreported, and Unregulated Fishing," Republic of Mauritius Ministry of Fisheries and Rodrigues, 2 March 2001, http://extwprlegs1.fao.org/docs/pdf/mat165160.pdf.

77 "The Fisheries Sector Of Mauritius Economics Essay," UK Essays, 5 December 2016, https://www.ukessays.com/ essays/economics/the-fisheries-sector-of-mauritiuseconomics-essay.php.
78 Food and Agriculture Organization of the United Nations, "Guidelines for the Preparation of National Reports to the IOTC Scientific Committee in 2017," IOTC-2017-SC20-NR17, 15 November 2017, http://www.iotc.org/sites/default/ files/documents/2017/11/IOTC-2017-SC20-NR17 Mauritius.pdf.

79 "Mauritius: Fisheries Partnership Agreement," European Commission, https://ec.europa.eu/fisheries/cfp/ international/agreements/mauritius en, accessed 25 February 2019.

80 Subhas Chandra Bauljeewon, Divisional Scientific Officer, Seafood Hub, Ministry of Ocean Economy, Marine Resources, Fisheries and Shipping, email to author, 7 March 2019.

81 "Albion Fisheries Research Centre," Republic of Mauritius Ministry of Ocean Economy, http://oceaneconomy.govmu. org/English/Pages/Albion-Fisheries-Research-Centre.aspx, accessed 25 February 2019.

82 Cassandra De Young (ed.), "Review of the State of World Marine Capture Fisheries Management: Indian Ocean," FAO Fisheries Technical Paper No. 488 (Rome: FAO, 2006), http://www.fao.org/3/a0477e/a0477e0z.htm.

83 "Port State Control and Import Export Division," Republic of Mauritius Ministry of Ocean Economy, Marine Resources, Fisheries and Shipping, http://oceaneconomy.govmu. org/English/Departments/Pages/MCS -VMS Port-StateControl-and-ImportExport-Division.aspx, accessed 25 February 2019.

84 Republic of Mauritius, "Road Map to Eliminate Illegal Fishing in the Western Indian Ocean," 14 June 2016, http://www.govmu.org/English/News/Pages/Road-mapto-eliminate-illegal-fishing-in-the-western-Indian-Oceanbeing-finalised-.aspx.

85 "FAO Country Profiles: Madagascar," Food and Agriculture Organization of the United Nations, http://www.fao. org/countryprofiles/index/en/?iso3=mdg, accessed 25 February 2019.

86 Christian Marchese, "Biodiversity Hotspots: A Shortcut for a More Complicated Concept," Global Ecology and Conservation 3, January 2015, https://doi.org/10.1016/i. gecco.2014.12.008.

87 "The Poorest Countries in the World (2019-2023)," Focus Economics, https://www.focus-economics.com/blog/thepoorest-countries-in-the-world, accessed 25 February 2019. 
88 Frédéric Le Manach, Charlotte Gough, Frances Humber, Sarah Harper, and Dirk Zeller, "Reconstruction Of Total Marine Fisheries Catches For Madagascar (1950-2008)," The Sea Around Us, 2011, http://www.seaaroundus. org/doc/publications/chapters/2011/LeMenach-et-alMadagascar.pdf.

89 "Madagascar," Food and Agriculture Organization of the United Nations, http://www.fao.org/3/a-br796e.pdf, accessed 25 February 2019.

90 "State of Fisheries and Aquaculture in the World 2018," Food and Agriculture Organization of the United Nations, 2018, http://www.fao.org/state-of-fisheries-aquaculture.

91 Rebecca Short, Rajina Gurung, Nicholas Hull, and E.J. Milner-Gulland, "The Use of Mosquito Nets in Fisheries: A Global Perspective," PloS ONE 13(1), 31 January 2018, https://iournals.plos.org/plosone/article?id=10.1371/ journal.pone.0191519.

92 Wonder Chinhuru, "Madagascar Fisheries Ravaged by Foreign Plunder, Equal Times, 23 March 2015, https:// www.equaltimes.org/madagascar-fisheries-ravaged-by.

93 "Six Years for Improving Statistic Data Collection in Comoros," Indian Ocean Tuna Commission, 2017, http:// www.iotc.org/sites/default/files/documents/2017/11/ IOTC-2017-WPDCS13-15 - COM.pdf.

94 "Comoros," Food and Agriculture Organization of the United Nations, http://www.fao.org/fishery/facp/45/en, accessed 26 February 2019.

95 "Fishery and Aquaculture Country Profiles: The Union of the Comoros," Food and Agriculture Organization of the United Nations, http://www.fao.org/figis/pdf/fishery/facp/COM/ en?title=FAO $\% 20$ Fisheries $\% 20 \% 26 \% 20$ Aquaculture $\% 20$ -\%20Fishery $\% 20$ and $\% 20$ Aquaculture $\% 20$ Country $\% 20$ Profiles\%20-\%20The\%20Union\%20of\%20the\%20Comoros, accessed 26 February 2019.

96 "21st Scientific Committee (SC21)," Indian Ocean Tuna Commission,http://www.iotc.org/meetings/21st-scientificcommittee-sc21, accessed 26 February 2019.

97 "Comoros," The Sea Around Us, http://www.seaaroundus. org/doc/publications/chapters/2015/Doherty-et-alComoros.pdf, accessed 26 February 2019.

98 "Comoros: Fisheries," European Commission, https:// ec.europa.eu/fisheries/cfp/international/agreements/ comoros en, accessed 26 February 2019.
99 "Fight Against Illegal Fishing: Commission Lists Saint Vincent and the Grenadines and the Comoros as Non-cooperating," European Commission, 23 May 2017, https://ec.europa. eu/fisheries/fight-against-illegal-fishing-commission-listssaint-vincent-and-grenadines-and-comoros-non en.

100 Lennart Dodoo, "European Union Warns Liberia to Control Illegal Fishing," IUU Watch, 24 May 2017, http://www. iuuwatch.eu/2017/05/european-union-warns-liberiacontrol-illegal-fishing/.

101 "The Seychelles Archipelago," SeychellesNation.sc, http:// www.nation.sc/article.html?task=pdf\&id=337, accessed 26 February 2019.

102 "Seychelles Overview," World Bank Group, https://www. worldbank.org/en/country/seychelles/overview, accessed 26 February 2019.

103 "Seychelles," Food and Agriculture Organization of the United Nations, http://www.fao.org/3/a-br801e.pdf, accessed 26 February 2019.

104 Karine Rassool, "Challenges, Prospects, and Opportunities: Seychelles Fisheries Sector," UNCTAD, 22 March 2017, https://unctad.org/meetings/en/Presentation/ted-ditc22032017-4-Rassool-NEW.pdf.

105 "FAO Fishery Country Profile: The Republic Of Seychelles," Food and Agriculture Organization of the United Nations, http://www.fao.org/fi/fcp/en/sYc/profile.htm, accessed 26 February 2019.

106 Jesus Iborra Martin, "Fisheries in the Seychelles and Fisheries Agreements with the EU," European Parliament Directorate-General for Internal Policies, 4 September 2011, http://www.europarl.europa.eu/RegData/etudes/ note/join/2011/460060/IPOL-PECH NT(2011)460060 EN.pdf.

107 "Fisheries Statistical Report Year: 2015 Seychelles," OceanDocs, 13 September 2017, https://www.oceandocs. org/bitstream/handle/1834/9866/SFA\%20FISHERIES\%20 BULLETIN\%202015_Final.pdf?sequence=1\&isAllowed=y.

108 "Comprehensive Review of MCS Capacity in the ESA-IO Region," Food and Agriculture Organization of the United Nations, http://www.fao.org/3/a-az384e.pdf, accessed 26 February 2019.

109 Daniel Laurence, "Two Boats from Sri Lanka Intercepted in Waters of Seychelles for Illegal Fishing," Seychelles News Agency, 7 November 2018, http:// www.seychellesnewsagency.com/articles/10020/ Two+boats+from+Sri+Lanka+intercepted+in+waters+ of+Seychelles+for+illegal+fishing. 
110 Salifa Karapetyan, "6 Sri Lankan Nationals Held in Seychelles on Illegal Fishing Charge," Seychelles News Agency, 12 June 2018, http://www.seychellesnewsagency. com/articles/9278/+Sri+Lankan+nationals+held+in +Seychelles+on+illegal+fishing+charge.

111 Seychelles Fishing Authority: Monitoring Control and Surveillance,"http://www.sfa.sc/index.php/sections/ monitoring-control-and-surveillance, accessed 26 February 2019.

112 Seychelles Regional Coordination Operations Center Twitter, “@RCOC_Center,” https://twitter.com/rcoc center ?lang=en, accessed 26 February 2019.

113 "Somalia," Food and Agriculture Organization of the United Nations, http://www.fao.org/3/a-br798e.pdf, accessed 26 February 2019.

114 International Organization for Migration, "Dimensions of Crisis on Migration in Somalia," Working Paper February 2014, https://www.iom.int/files/live/sites/iom/files/Coun try/docs/Dimensions-of-Crisis-on-Migration-in-Somalia. pdf.

115 "Somalia Economy Profile 2018," IndexMundi. https:// www.indexmundi.com/somalia/economy profile.html, accessed 26 February 2019.

116 Federal Republic of Somalia, "Somalia Economic Update August 2018," Edition 3, 13 September 2018, http://documents.worldbank.org/curated/en/975231 536256355812/text/REPLACEMENT-PUBLIC-SomaliaEconomic-Update-3-FINAL.txt.

117 United Nations Security Council Resolution 2383, "The Situation in Somalia," S/RES/2383, 7 November 2017, http://unscr.com/en/resolutions/2383.

118 "Somalia: National Report 2018," Indian Ocean Tuna Commission, 21 November 2018, http://www.iotc.org/fr/ documents/SC/21/NR24.

119 Sarah M. Glaser, Paige M. Roberts, Robert H. Mazurek, Kaija J. Hurlburt, and Liza Kane-Hartnett, "Securing Somali Fisheries Report," Secure Fisheries, 16 September 2015, https://securefisheries.org/report/securing-somalifisheries.

120 Tim Cashion, Sarah M. Glaser, Lo Persson, Paige M. Roberts, and Dirk Zeller, "Fisheries in Somali Waters," Secure Fisheries, January 2018, https://securefisheries.org/ fisheries-somali-waters.
121 "Report on Presumed IUU Fishing Activities in the EEZ of Somalia," Indian Ocean Tuna Commission, IOTC-2015S19-Inf01, 27 April 2015, https://cdn2.hubspot.net/ hubfs/183611/Landing Page Documents/IUU Activities in Somalia- eE use case.pdf.

122 Preetu Nair, "INS Sunayna Seizes Arms and Ammunition from Illegal Fishing Vessel," Times of India, 9 December 2018, https://timesofindia.indiatimes.com/india/ins-sunaynaseizes-arms-and-ammunition-from-illegal-fishing-vesseloff-somalia/articleshow/67011207.cms. 


\section{FISHING ACTIVITY SIGHTING REPORT}

\section{General Information}

5 Additional Observations

1. Date (Month/Day/Year):

2. Time (GMT):

3. Estimated position of observed vessel (lat/log): xx-xx.x N/S xxx-xx.x E/W

4. Observed activity (Fishing, Transit, Transhipping, Refueling/Bunkering):

\section{Primary Vessel Information}

1. Vessel name:

2. Vessel flag:

3. IMO number (if observed, 7 digits):

4. Hull Number:

5. Evidence of Altered or Removed numbers/name:

6. IRCS (International Radio Call Sign):

7. MMSI (nine digit number):

8. Other identification marking:

9. Vessel type (Fishing Vessel, Refrigerated Cargo Ship, Refueler/Bunker):

\section{Vessel Description}

1. Length:

2. Beam:

3. Gross Tonnage:

4. Paint Scheme:

\section{Vessel Contact Information}

1. Phone Number:

2. Fax Number:

3. Email Address:

one earth F U T U R E

\section{8 \\ Photographs/Video Attached}

1. Yes/No

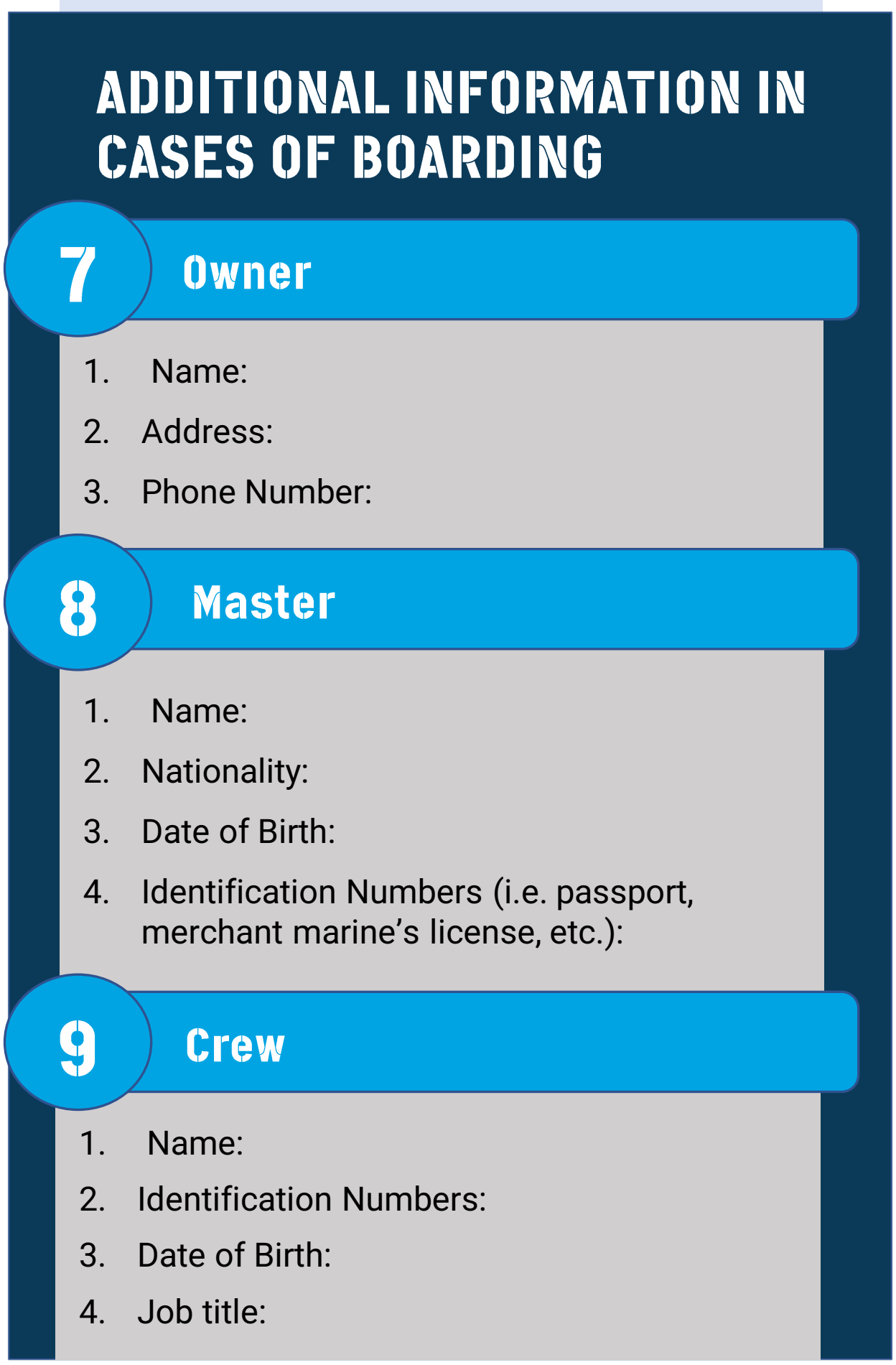




\section{ONE EARTH FUTURE}

\section{oneearthfuture.org $\$$}

One Earth Future (OEF) is a self-funded, private operating foundation seeking to create a more peaceful world through collaborative, data-driven initiatives. OEF focuses on enhancing maritime cooperation, creating sustainable jobs in fragile economies, and research which actively contributes to thought leadership on global issues. As an operating foundation, OEF provides strategic, financial, and administrative support allowing its programs to focus deeply on complex problems and to create constructive alternatives to violent conflict.

\section{SECURE FISHERIES}

\section{securefisheries.org}

Secure Fisheries is a program of One Earth Future. Secure Fisheries works with local, regional, and international stakeholders to strengthen fisheries governance, combat illegal fishing, and promote sustainability in fragile and postconflict regions as a pathway towards greater peace and stability.

\section{CONTACT US}

\section{* \\ SECURE FISHERIES \\ Advancing Sustainable Fisheries \\ a program of One Earth Future}

\section{one earth F U T U R E}

Peace Through Governance 